\title{
COST ACCOUNTS ON SOME NEW YORK FARMS
}

567

.L2

Copy 1

\section{A THESIS}

Presented to the Faculty of the Graduate School OF CORNELL. UNIVERSITY FOR THE DEGREE OF

DOCTOR OF PHILOSOPHY

BY

CARL E. LADD

Reprinted from Bulletin 377, N. Y. State College of Agriculture 



\title{
COST ACCOUNTS ON SOME NEW YORK
} FARMS

\section{A THESIS}

Presented to the Faculty of the Graduate School of Cornell University for the Degree of DOCTOR OF PHILOSOPHY

\author{
BY \\ CARL E. LADD
}




$$
\begin{array}{r}
S 567 \\
L^{2}
\end{array}
$$

In Exchange.

Cornell Univ. DEC 4 - 1916 


\section{CONTENTS}

Introduction . . . . . . . . . . . . . . . . . . 773

Methods used in investigation ....................... 773

System of accounting . . . . . . . . . . . . . . . 773

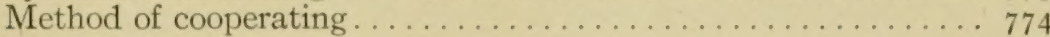

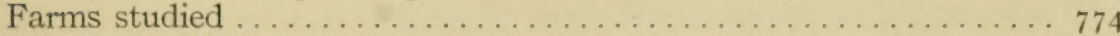

Types of farming ........................... 774

Average size of farms cooperating ................. 775

Results ................................. 775

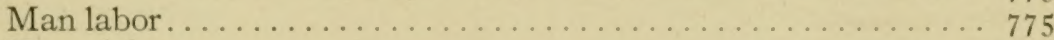

Horse labor. . . . . . . . . . . . . . . . . . 776

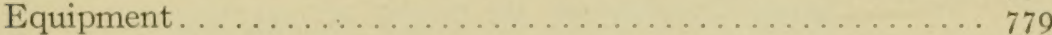

Crops ............................... 780

Timothy and clover hay ..................... 780

Oats............................. 782

Silage corn . . . . . . . . . . . . . . . . 784

Potatoes ........................... 786

Other crops (alfalfa, barley, beans, buckwheat, cabbage, wheat) . . . . . . . . . . . . . . . . 788

Dairy cows.............................. 790

Distribution of labor . . . . . . . . . . . . . . . . 793

By enterprises........................... 793

By farms .............................. 794 



\title{
COST ACCOUNTS ON SOME NEW YORK FARMS
}

\author{
C. E. $\mathrm{LADD}^{1}$
}

\section{INTRODUCTION}

Few results of farm cost accounts have been published. The Minnesota Agricultural Experiment Station, in cooperation with the Bureau of Crop Estimates of the United States Department of Agriculture, has published results of complete sets of cost accounts for a number of farms in Minnesota, ${ }^{2}$ while several other States have published results of limited studies of the cost of farm products.

In this bulletin results are given from complete sets of cost accounts on New York farms for the years I9I2 and I9I3. - In I9I2 accounts were closed on eighteen farms. Fourteen of these were real farms, run in a practical manner, and the results are sufficiently accurate to be used for further study. During that year much experimenting was done with various methods of accounting. In $\mathrm{I}_{9} \mathrm{I} 3$ accounts were obtained from thirty-three farms.

\section{METHODS USED IN INVESTIGATION SYSTEM OF ACCOUNTING}

The system of accounting used was essentially the same as that described in Warren's Farm Management and by the writer in another publication. ${ }^{3}$ On each farm an inventory was made at the beginning and at the end of the year, care being taken to get the actual farm value of each article inventoried. In the case of animals, the value was placed at what the owner could get for them at a normal sale. Hay, grain, stalks, and other supplies were inventoried at the market price, less the cost of marketing.

Each farmer had two account books, one marked Work Report and the other marked Ledger. In the work report a record was kept of all the man hours and the horse hours worked on the farm, classified on separate pages under the name of the enterprise for which the work was done. In the ledger an account was kept of all the money paid out or received.

I The writer wishes to acknowledge his appreciation of the carefulness and reliability of the farmers: who cooperated in this work. Thanks are due also to Professor G. F. Warren, under whose direction the work was done, for many helpful suggestions and criticisms; to Professor K. C. Livermore, Professor A. L. Thompson, and D. S. Fox, of Cornell University, for many valuable suggestions; and to E. H. Thomson and C. M. Bennett, of the office of Farm Management, United States Department of Agriculture, for assistance and encouragement in collecting the data.

Results of accounts kept by E. B. Brunson and E. V. K. Dwinelle on six farms are included. All the accounts except on these six farms vere kept in cooperation with the Office of Farm Management, United States Department of Agriculture.

2 Cooper, T. B. The cost of Minnesota dairy products. Minnesota Agr. Exp. Sta. Bul. I24.

Hays, W. M., and Parker, E. C. Cost of producing farm products. U. S. Stat. Bur. Bul. 48.

Peck, F. W. The cost of producing Minnesota farm products, 1908-1912. Minnesota Agr. Exp. Sta. Bul. 145 .

'Ladd, C. E. A system of farm accounting. U. S. Agr. Dept. Farmers' bul. 572 :1-15. 1914. 
These amounts were entered under separate accounts in the ledger as the transactions occurred. Transfers of feed or other items from one enterprise to another were made in the ledger.

At the end of the year the total number of man hours worked on the farm was found from the work report. The total cost of labor was found from the ledger. To find the labor cost per hour, the total cost was divided by the total hours worked. All labor was then charged at this rate to the various enterprises, according to the number of hours worked on each. The cost of horse labor was found and distributed in the same way. The cost of equipment use for the year was distributed among the various enterprises on the basis of the number of horse hours worked on each enterprise.

Where manure was used, ordinarily 40 per cent of the value of the manure and 40 per cent of the cost of applying it was charged to the crop receiving the application; 30 per cent of each value was charged to the next crop on the same field; 20 per cent to the third crop; and ro per cent to the fourth. These percentages were varied somewhat according to the physical characteristics of the soil.

Further details of the system used may be found in either of the two references already cited.

\section{METHOD OF COOPERATING}

The work was undertaken, not as an extension, but as an investigative, enterprise. In most cases farmers were not asked to cooperate. After the first year so many farmers applied for the opportunity that the question became one of selecting those who seemed most likely to keep accurate records.

The College furnished all account books, and the college representative visited the farms to inspect the accounts, aided in taking inventories, and closed the accounts at the end of the year. Factors were worked on all the accounts at the end of the year, and these, together with a letter of explanation and criticism of results, were sent to the farmer. In return for these services, the College received a copy of each cooperator's books, with the understanding, however, that in using individual results the cooperator's name should not be given. The cooperators as a whole have done their part of the work faithfully, and each year a large proportion have kept on with the work for the following years.

\section{FARMS STUDIED \\ TYPES OF FARMING}

Several types of farming are represented in the study. In I9I3, out of thirty-one farms twenty-two had herds of five or more cows. Five of 
these herds consisted of purebred stock, and seventeen were grade herds or largely grades with a few purebreds. Many of these dairymen had cash crops to sell, some of these crops being potatoes, cabbage, beans, hay, wheat, buckwheat, apples, hops, tobacco, and peas. The remaining nine farmers kept only enough cows for home use, or perhaps sold a small surplus of milk or butter to neighbors. One of the nine farmers in this class fed steers, one fed sheep and steers, and one fed dry stock through the winter, in order to obtain manure and to make use of straw, bean pods, cornstalks, or poor hay. These nine farmers were selling such crops as potatoes, cabbage, beans, hay, wheat, apples, grapes, and small fruits.

Several of the farms that are located near large cities raised truck crops to a considerable extent.

\section{AVERAGE SIZE OF FARMS COOPERATING}

The average farm of New York State, according to the United States Census of 1910, comprises 102.2 acres, of which 68.8 acres are improved. The farms for which accounts were kept in I9I 3 average 203.6 acres and III. 5 crop acres. The fact that these farms are about twice as large as the average should be kept in mind in interpreting the results of the study.

\section{RESULTS}

\section{MAN LABOR}

The usual wages paid for farm help in I9I2 and I9I3 ranged from $\$ 1.25$ to $\$ 2$ a day for help given one or two meals; from $\$_{25}$ to $\$ 32$ a month, with board; from $\$ 30$ to $\$ 40$ a month, without board. Higher wages were usually paid for short periods of time in the summer, and lower wages for the winter months. The cost of man labor on the farms studied is given in table $\mathrm{I}$ :

table i. Cost of Man Labor, Including Board, House Rent, and All Other EXPENSE

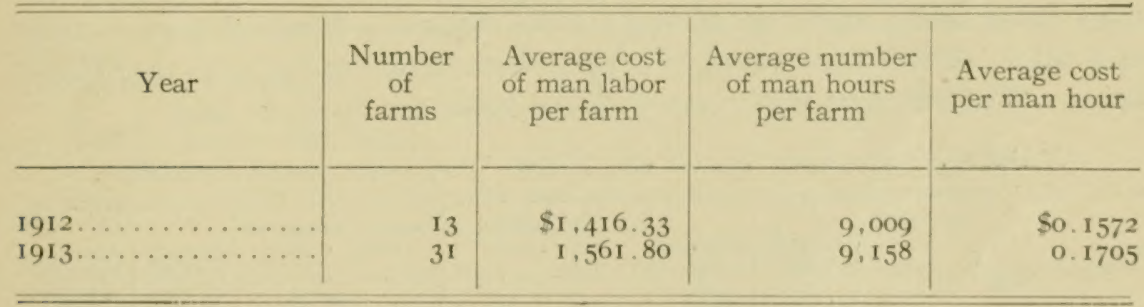

Nine farms had a labor cost of more than $\$_{2}, 000$, while eleven had a labor cost of less than $\$ 1000$. One farm worked 2 I,743 man hours and had an average of about seven men; one farm worked 3695 man hours and had an average of about one and one-half men. Four farms had 
a labor cost of less than I 2 cents an hour, seven had a labor cost of more than 20 certs an hour, and twenty-three had a labor cost between I $_{5}$ and 20 cents an hour.

The average distribution of labor costs is shown in table 2 :

TABLE 2. Average Distribution of Labor Costs

\begin{tabular}{|c|c|c|c|c|}
\hline & \multicolumn{2}{|c|}{1912} & \multicolumn{2}{|c|}{ I9I3 } \\
\hline & $\begin{array}{l}\text { Average cost } \\
\text { per farm }\end{array}$ & $\begin{array}{l}\text { Per cent } \\
\text { of total }\end{array}$ & $\begin{array}{l}\text { Average cost } \\
\text { per farm }\end{array}$ & $\begin{array}{l}\text { Per cent } \\
\text { of total }\end{array}$ \\
\hline Cash paid........ & $\$ 517 \cdot 30$ & 36 & $\$ 587$. I I & \\
\hline $\begin{array}{l}\text { Board furnished .............. } \\
\text { House rent and miscellaneous }\end{array}$ & 224.68 & 16 & I 59.37 & $\begin{array}{ll}30 \\
\text { IO }\end{array}$ \\
\hline 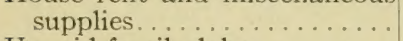 & $3^{8} .83$ & 3 & 66.83 & \\
\hline Unpaid family labor......... & 102.98 & 7 & 174.49 & II \\
\hline Operator's labor. ........... & $532 \cdot 54$ & 38 & 574.00 & 37 \\
\hline Total. & $\$ 1,416.33$ & & $\$ I, 56 I .80$ & \\
\hline
\end{tabular}

The amount paid in cash was about equal to the value of the operator's labor. Twenty farms used some family labor other than the operator's. Thirty-seven farms furnished board, and eleven farms furnished tenant houses, to labor.

\section{HORSE LABOR}

In finding the cost of horse labor, the cost of keeping work horses was not separated from the cost of keeping boarded horses and the cost of raising colts. All horses were reduced to a horse unit basis, two colts or one horse being counted as equal to one horse unit.

In I9I2, on fourteen farms, there were 73.8 horse units, made up of 72 work horses and 3.5 colts. In I9I 3 , on thirty-one farms, there were I 89.8 horse units, made up of I 73.5 work horses, 4 boarded horses, and 24.6 colts. Colts were raised in I9I 2 on four farms, and in I 9 I 3 on fifteen farms. The averages that concern horse labor are given in table 3 :

TABle 3. Average Value per Horse Unit, and Other Factors

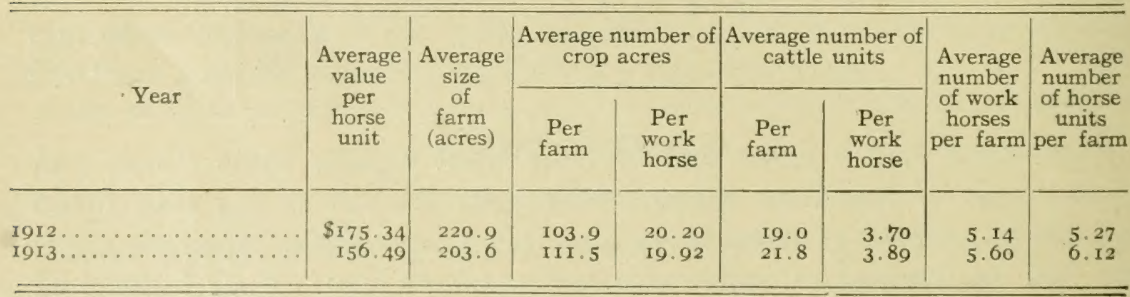


The arerace value per horse unit on different farms varied from $S_{i+\text {. }}$ io to $\$ 267.56$. The cheapest horses were on a small, gravelly farm, where small, light animals were userl; the highest-priced horses were on a large farm with a very heayy day soil. One farm hat an average of ir.5 work horses for the year, while the smallest number was 2. The number of crop acres per work horse varied with the size of farm and the crops raiserl. One farm of $\mathrm{r}_{72}$ acres hat +1.3 (rop acres per work horse. On this farm there were 22 acres of hay, 7 acres of oats and wheat, and 12 acres of potatoes, for each work horse. One farm of 53 acres had i crop acres per work horse. The average figure for crop acres per work horse checks closely with the results for farms of the same size in Livingston and Jefferson Counties. ${ }^{4}$

The cost of keeping a horse unit for one year is apportioned as shown in table 4 :

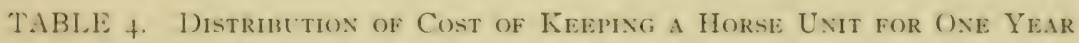
(73.8 horse units in 1912, 189.8 horse units in 1913)

\begin{tabular}{|c|c|c|c|c|}
\hline & \multicolumn{2}{|c|}{1912} & \multicolumn{2}{|c|}{1913} \\
\hline & $\begin{array}{l}\text { Average cost } \\
\text { per horse } \\
\text { unit }\end{array}$ & $\begin{array}{l}\text { Per cent } \\
\text { of total } \\
\text { cost }\end{array}$ & $\begin{array}{l}\text { Average cost } \\
\text { per horse } \\
\text { unit }\end{array}$ & $\begin{array}{l}\text { Per cent } \\
\text { of total } \\
\text { cost }\end{array}$ \\
\hline Forage and bedding........ & $\$ 42.96$ & 27 & $\$ 40.90$ & 28 \\
\hline 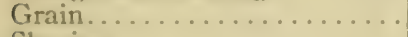 & $57 \cdot 72$ & 36 & 46.39 & 32 \\
\hline Shoeing. . . . . . . . . . . . & 4.24 & 3 & 4.87 & 3 \\
\hline Veterinary and medicine..... & 2.00 & I & 0.69 & I \\
\hline Man labor . . . . . . . . . . & 23.55 & 15 & 22.97 & 16 \\
\hline Equipment labor........... & 0.82 & I & 0.67 & I \\
\hline Use of buildings. . . . . . . . . & 5.75 & 3 & 5.92 & 4 \\
\hline 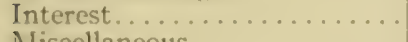 & 8.77 & 5 & 7.82 & 5 \\
\hline $\begin{array}{l}\text { Miscellaneous. . . . . . . . . . } \\
\text { Depreciation. . . }\end{array}$ & $\begin{array}{r}0.38 \\
* 14.03\end{array}$ & $\cdots \cdots$ & $\begin{array}{r}2.63 \\
+12.10\end{array}$ & $\frac{2}{8}$ \\
\hline & SIfo & & & \\
\hline 1 otal cost........... & $\$ 100.22$ & & $\$ 1+4.90$ & \\
\hline Manure.................. & $\$ 12.34$ & & $\$ 12.63$ & \\
\hline Miscellaneous receipts....... & 0.28 & & $3 \cdot 33$ & \\
\hline $\begin{array}{l}\text { Total manure and mis- } \\
\text { cellaneous........... }\end{array}$ & $\$ 12.62$ & & SI 5.96 & \\
\hline Net cost. . . & $\$ 147.60$ & & $\$ 129.00$ & \\
\hline
\end{tabular}

* Appreciation on four farms.

† Appreciation on eight farms.

The arerage cost of keeping a horse unit for one year, after dedlucting value of manture and miscellaneous receipts, was $\$_{1+7}$. (10 in 1012 and

\footnotetext{
1Warren, G. F. Some important factors for success in general farming and in dairy farming. Cornell Univ. Agr. Exp. Sta. Bul. 349:670.
} 
$\mathrm{S}_{129}$ in I9I3. The total cost of forage, bedding, and grain per horse unit was $\$ 100.68$ in 19 I 2 and $\$ 87.29$ in r9I3. All grain and forage was cheaper in I9I3 than in I9I2. Seven farms had a forage and bedding cost per horse unit below $\$ 30$, while for eight farms this cost was above $\$ 55$. Of the seven farms with a low cost, five were in regions where there was a shortage in forage and bedding that year.

Four farms had a grain cost of less than $\$ 30$ per horse unit, and eleven farms had a grain cost of over $\$ 60$ per horse unit. None of the farms with a low forage and bedding cost had a low grain cost. On two of the farms with a low grain cost alfalfa hay was used for feed; on one the horses were worked an average of only r.8 hours a day; and on the fourth the horses were kept in very poor condition. Four of the farms with a high grain cost had a low forage and bedding cost, and seemed to replace forage with grain.

Six farms had a man labor cost per horse unit of more than $\$ 35$. None of these had winter dairies or much winter work, and so probably spent more chore time on horses than was necessary. Four of these farms kept horses in a building separate from the other stock, and labor was inefficiently used in doing chores. Eleven farms had a man labor cost per horse unit of less than \$15. All of these had barns very efficiently arranged for doing chores.

The relation of the amount of business done to the cost of horse labor is shown in table 5 :

Table 5. Relation of Size of Business to Cost per Hour of Horse Labor, i9i3

\begin{tabular}{|c|c|c|c|}
\hline Size of business measured in total horse hours & $\begin{array}{l}\text { Number } \\
\text { of } \\
\text { farms }\end{array}$ & $\begin{array}{l}\text { Average } \\
\text { number } \\
\text { of horse } \\
\text { hours }\end{array}$ & $\begin{array}{l}\text { Cost per } \\
\text { horse } \\
\text { hour }\end{array}$ \\
\hline 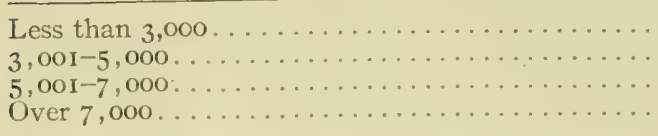 & $\begin{array}{l}8 \\
9 \\
7 \\
7\end{array}$ & $\begin{array}{l}2,421 \\
3,954 \\
6,200 \\
9,442\end{array}$ & $\begin{array}{l}\$ 0.1788 \\
\text { o. } 1730 \\
\text { o. } 1465 \\
\text { o. } 1287\end{array}$ \\
\hline
\end{tabular}

Records for eight farms are given in both the I9I 2 and I9I 3 tabulations. Horses on these farms were fed more when feed was cheaper. The comparative quantities of feed for the two years are shown in table 6 :

Table 6. Average Quantities of Feed per Horse Unit per Year on Eight FARMS IN I9I2 AND ON THE SAME FARMS IN I9I3

\begin{tabular}{|c|c|c|}
\hline & 1912 & I9I 3 \\
\hline $\begin{array}{l}\text { Pounds of grain } \ldots \ldots \ldots \ldots \ldots \ldots \ldots \\
\text { Pounds of forage and bedding } \ldots \ldots \ldots \ldots \ldots \ldots\end{array}$ & $\begin{array}{l}3,846 \\
7,099\end{array}$ & $\begin{array}{l}4,434 \\
7,960\end{array}$ \\
\hline
\end{tabular}




\section{EQUIPMENT}

Important special machinery - such as cream separators, inculators, and gasoline engines, which are not used with horses - was inventoried ander the enterprises for which it was userl. All other machinery, including harnesse's and small tools, was inventoried under Equipment. The costs for this equipment are given in table 7 :

TABLE 7. EQUipMENT Costs

\begin{tabular}{|c|c|c|c|c|c|c|c|}
\hline Year & $\begin{array}{l}\text { Num- } \\
\text { ler of } \\
\text { farms }\end{array}$ & $\begin{array}{l}\text { Investment } \\
\text { in equipument } \\
\text { per farm }\end{array}$ & $\begin{array}{l}\text { Invest- } \\
\text { ment per } \\
\text { crop acre }\end{array}$ & $\underset{\substack{\text { Annual } \\
\text { cust }}}{ }$ & $\begin{array}{l}\text { Per cent of } \\
\text { average in- } \\
\text { vestment in } \\
\text { annual cost }\end{array}$ & $\begin{array}{c}\text { Cost per } \\
\text { ('rul) } \\
\text { acre }\end{array}$ & $\begin{array}{l}\text { Cost per } \\
\text { hurse } \\
\text { hour }\end{array}$ \\
\hline 1912. & I3 & $\$ 981.46$ & $\$ 9.80$ & $\$ 249.62$ & 25.4 & $\$ 2.49$ & So.0503 \\
\hline 1913. & $3 I$ & 922.93 & 8.28 & 271.56 & 29.4 & 2.44 & 0.0513 \\
\hline
\end{tabular}

Qne farm owned equipment worth $s_{3}+1$, and one owned equipment worth Sig02.50. The anmual cost of equipment per (rop) acre was S2 $_{40}$ in 1012 and $\$ 2.4+$ in 1013. . The use of equipment wats charged (nn the hasis of the horse hours used on each enterprise. The use of equipment cost 5.03 cents per horse hour in I9I2 and 5.13 cents in I9I3.

The average distribution of the annual cost of equipment is shown in table 8 :

table 8. Average Distribution of Annual Cost of Equipmext

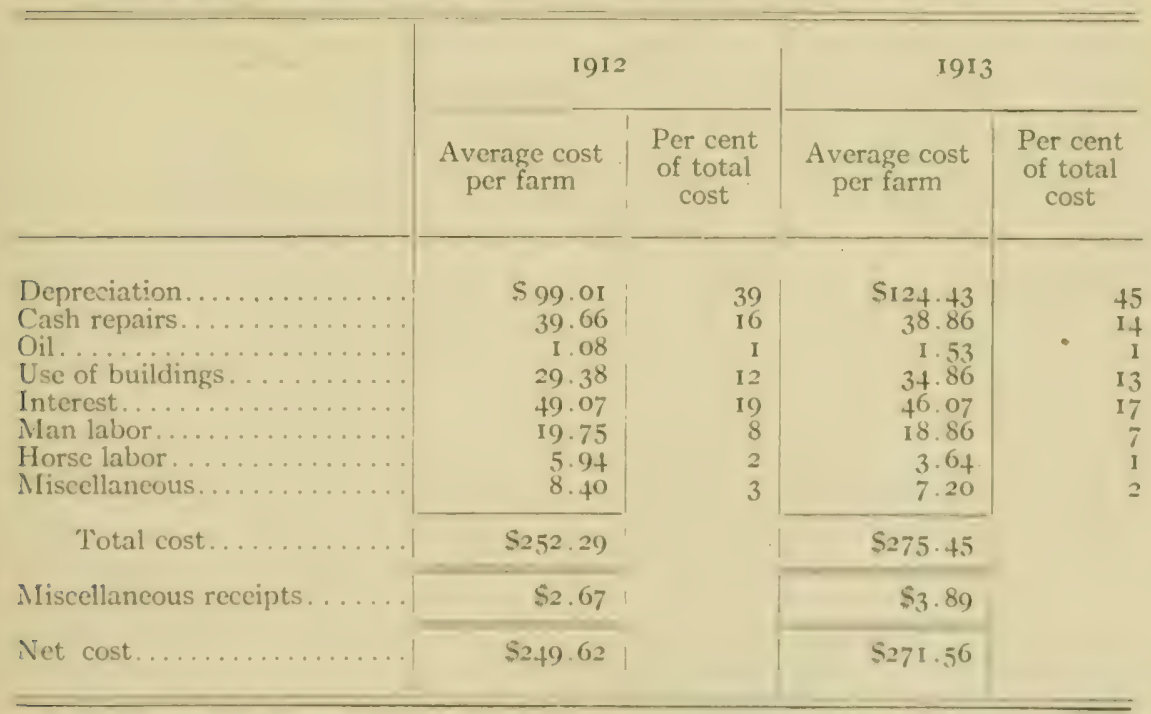

The arerage annual depreciation on equipment wats 10.1 fer ent of the average inventory in 1012 , and 13.5 per cent of the average inventory 
in ror3. The inventory value of equipment is of course much less than the cost when new.

\section{CROPS}

\section{TIMOTHY AND CLOVER HAY}

In its climate, soils, and markets, New York State is well adapted for hay production. Nearly all the farms in the State raise hay. Of the total area in crops on cooperating farms, 38 per cent in I 9 I 2 , and 34 per cent

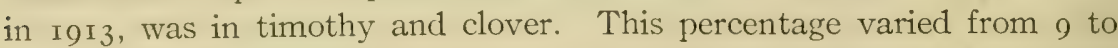
62 on individual farms. Only one farm with which accounts have been kept did not raise timothy and clover; this farm raised alfalfa. On several farms the hay account included small fields of alfalfa or oat and pea hay. These farms were not included in the tabulation. The average yield of timothy and clover hay for New York State was 1.25 tons per acre in I9I2, and I.I 4 tons per acre in I9I $3 .{ }^{5}$ The average yield on the cooperating farms was slightly higher than the average for the State. One farm had an average yield of 2.5 tons per acre, while on one farm the yield was only 0.66 ton per acre. Both these farms, however, made a profit in producing hay.

The data concerning the production of timothy and clover hay are given in table 9. Very little of this hay was marketed during the year.

TABle 9. Averages for Timothy and Clover Hay

\begin{tabular}{|c|c|c|}
\hline & 1912 & I9I3 \\
\hline 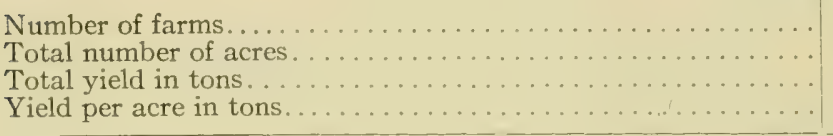 & $\begin{array}{r}12 \\
487 \cdot 5 \\
679 \cdot 5 \\
\text { I. } 39\end{array}$ & $\begin{array}{r}23 \\
823 \cdot 7 \\
\text { I } 185.9 \\
\quad 1.44\end{array}$ \\
\hline 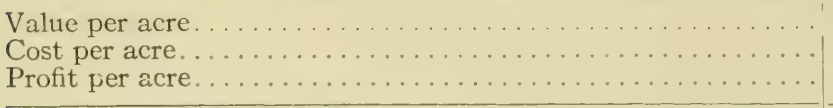 & $\begin{array}{r}\text { S } 5.53 \\
12.58 \\
2.95 \\
\end{array}$ & $\begin{array}{r}\$ 16.34 \\
12.31 \\
\quad 4.03 \\
\end{array}$ \\
\hline 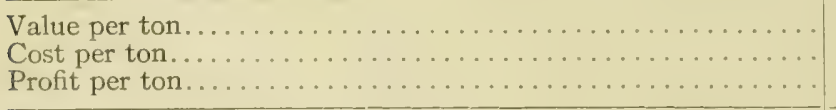 & $\begin{array}{r}\$ 11.15 \\
9.03 \\
2.12\end{array}$ & $\begin{array}{r}\$ \text { I I. } 35 \\
8.55 \\
2.80\end{array}$ \\
\hline Profit per man hour $\ldots \ldots \ldots \ldots \ldots \ldots \ldots \ldots \ldots \ldots$ & $\$ 0.27$ & $\$ 0.37$ \\
\hline $\begin{array}{l}\text { Man hours per acre } \ldots \ldots \ldots \ldots \ldots \ldots \ldots \ldots \ldots \ldots \ldots \ldots \ldots \ldots \ldots \ldots \ldots \ldots \\
\text { Horse hours per acre } \ldots \ldots \ldots \ldots \ldots \ldots \ldots \ldots \ldots\end{array}$ & $\begin{array}{l}\text { I I. } 03 \\
10.50\end{array}$ & $\begin{array}{l}10.80 \\
10.25\end{array}$ \\
\hline $\begin{array}{l}\text { Cost per acre aside from marketing } \ldots \ldots \ldots \ldots \ldots \ldots \ldots \ldots \ldots \\
\text { Cost per ton aside from marketing } \ldots \ldots \ldots \ldots \ldots \ldots\end{array}$ & $\cdots \cdots$ & $\$ .2 .11$ \\
\hline $\begin{array}{l}\text { Man hours per acre aside from marketing } \ldots \ldots \ldots \ldots \ldots \ldots \ldots \\
\text { Horse hours per acre aside from marketing } \ldots \ldots \ldots \ldots \ldots \ldots\end{array}$ & $\cdots \cdots$ & $\begin{array}{r}10.17 \\
9.74\end{array}$ \\
\hline
\end{tabular}

${ }^{5}$ U. S. Agr. Dept. Year book 1913:418. 
The value per ton used in the computation is in most cases farm value, and includes each year some hay of poor quality inventoried at \$s.5o or $\$ 9$ a ton.

Only five farms showed a loss on the hay account. One farm with a rield of 1.8 tons per acre marle a profit of $\$$ S.75 per ton. Fourteen farms made a profit per man hour of 50 cents or more.

The number of man hours per acre varied from $5 \cdot 7^{6}$, on a farm that harvested 100 acres with an average yield of only i ton per acre, u1) to 21.5 , on a farm with a yield of $\mathrm{I} \frac{1}{2}$ tons per acre. The latter farm was also very rough and hilly, and its hay was distributed in several small, rough, irregrtar fields. The number of horse hours on these two farms were 7.52 and 14.53 , respectively.

In I9 I 3 , of I I 85.9 tons of hay raised, 78.7 tons were marketed during the year. Some was held for wale later. The cost of production was separated from the cost of marketing. The use of buildings was charged as a cost of production. All time and charges beginning with the pressing of the hay or the removal of the hay from the mow, and including delivery to car or market, were charged to cost of marketing.

Most of the hay was sold on the understanding that the buyer should pay for the pressing. All marketing costs were figured on this basis and do not include the cost of pressing. In most cases the farmer furnished the men to pitch the hay to the press. The cost of marketing this hay is shown in table Io:

TABLE io. Cost of Marketrng 78.74 Tons of Hay, I9I 3

Man hours per ton.

Horse hours per ton. .

6.54

Average haul in miles.

5.21

3.00

Man labor enst frer tom

Inorse libluer cost fuer ton

Equipment cost per ton.

Total cost per ton.

SI. 14

0. 72

0.23

S2.(x)

The average distribution of the cost of producing hay in rora and in I9I3 is shown in table $I$.

The hay (rop hats a smaller proportion of its total cost in labor than hats any other erop grown on these farms. Labor (man, horse, and equipment) amounted to oser thirty per cent of the total cosi. C'se of limel, and manure and fertilizer, were the next most important costs. 
TABLE II. Averages for Hay

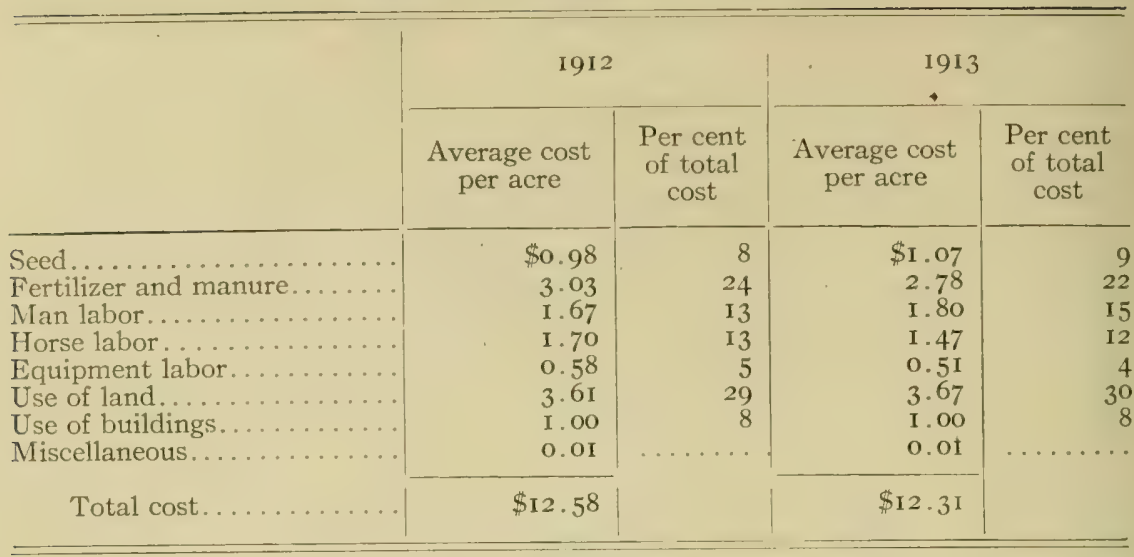

\section{OATS}

Oats are the most widely grown grain in New York State. In I9I 2 and I9I3 all except one of the cooperating farms raised oats.

There are several reasons why many New York farmers raise oats even though the account may show a loss. On many farms oats are grown as a nurse crop with which to seed timothy and clover. Oats are also used very extensively as horse feed. The work on this crop comes at a time of the year when few other crops compete with it for labor. Oat straw is the chief bedding on many farms.

The data concerning the production of oats are given in table 12:

TABLE 12. Averages FOR OAts

\begin{tabular}{|c|c|c|}
\hline & I9I 2 & I913 \\
\hline 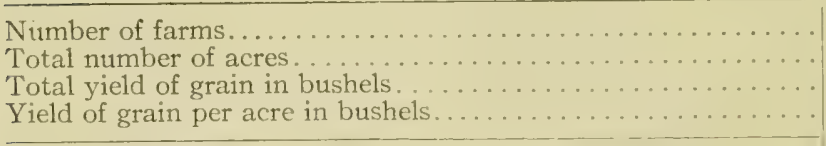 & $\begin{array}{r}10 \\
107.0 \\
4,723.0 \\
44.14\end{array}$ & $\begin{array}{r}27 \\
474 \cdot 3 \\
16,661 \cdot 5 \\
35 \cdot 13\end{array}$ \\
\hline 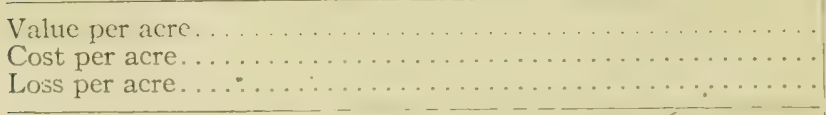 & $\begin{array}{r}\$ 20.62 \\
23.51 \\
2.89\end{array}$ & $\begin{array}{r}\$ 19.40 \\
22.34 \\
2.94\end{array}$ \\
\hline 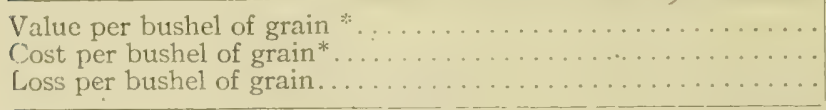 & $\begin{array}{r}\$ 0.39 \\
0.46 \\
0.07\end{array}$ & $\begin{array}{l}\$ 0.45 \\
0.53 \\
0.08\end{array}$ \\
\hline Loss per man hour . . . . . . . . . . . . . . . . . . . . . . & $\$ .12$ & $\$ .13$ \\
\hline $\begin{array}{l}\text { Man hours per acre } \ldots \ldots \ldots \ldots \ldots \ldots \ldots \ldots \ldots \ldots \ldots \ldots \ldots \ldots \ldots \ldots \ldots \ldots \\
\text { Horse hours per acre } \\
\text { Pounds of commercial fertilizer per acre } \ldots \ldots \ldots \ldots \ldots \ldots \ldots \ldots\end{array}$ & $\begin{array}{r}23.85 \\
33.12 \\
\cdots\end{array}$ & $\begin{array}{l}21.91 \\
30.80 \\
+20 I\end{array}$ \\
\hline
\end{tabular}

* Without straw.

t Average for the 19 farms on which commercial fertilizer was used. 
The average yield of oats in New York State was 30.8 bushels in 1912 and 33.5 bushels in $1913 .{ }^{6}$ The average yield on the farms studied was higher in 19 I 2 than in I9I3. The farms studied in I9 I 2 were located more generally in the grain-producing sections of the State. The average yield for $\operatorname{Ig}^{1} 3$ is close to the arerage for the State for that year, and all the cost factors are probably more typical of the State as a whole than are the factors for I9I2.

Eight farms raised oats at a cost of less than $\$ 20$ an acre, and on one farm the cost was as low as $\$ 13.30$ an acre. This farm raised oats after potatoes, without plowing the land for the oats; in this way a large part of the labor cost was saved.

Seven farms made a profit in producing oats. One farm raised 7.3 .6 bushels per acre at a cost of $\$ 10.20$. This farm made a profit of $\$_{1}+.00$ per acre, or $5^{8}$ cents per man hour, on its oats.

The average distribution of the cost of raising oats is shown in table i 3 :

table 13. Average Distribution of Cost of Producing Oats

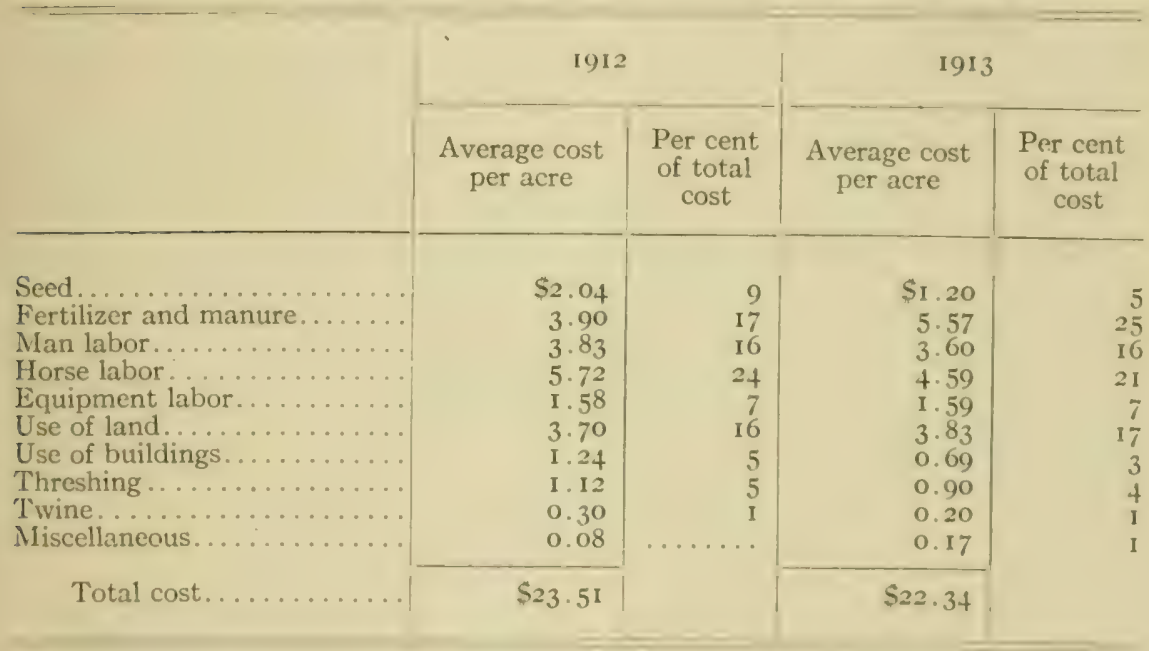

Labor cost (man, horse, and equipment) represents from +5 to 50 pe: cent of the total cost of growing uats. Use of land constitutes only from i6 to 17 per cent of the total cost. The fertilizer and manure charge against oats is rather laree. Most of the manure, however, is not applied directly to the oats, but is the estimated residual value from manure on the previous crop), which is generally a cultivated crop and ordinarily receives a large quantity of manure.

- U. S. Agr. Dept. Yearbook 1913:39r. 


\section{SILAGE CORN}

Many dairy farmers in New York State have ceased to raise corn for grain, and now raise this crop for silage only. This is a relatively new enterprise for most farmers, and the yields, costs, and valmes for silage corn are less known than are those for the older crops.

In order to obtain the total yield of silage corn on each farm, the silos were measured and their capacity was computed on the basis of tables given in King's Physics of Agriculture. The value per ton was estimated as about one-third that of timothy hay. This value was varied somewhat with the quality of the silage, the amount of grain contained, and other factors.

The data concerning the production of silage corn are given in table I 4 :

TABLE I4. Averages for Silage Corn

Number of farms. .

Total number of acres.

Total yield in tons.

Yield per acre in tons.

Value per acre

Cost per acre.

Profit or loss per acre.

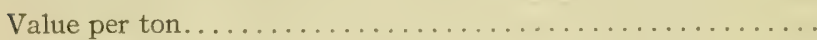

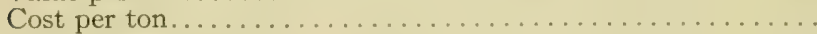

Profit or loss per ton.

Profit or lo:s per man hour.

Man hours per acre.

Horse hours per acre.

\begin{tabular}{|c|c|}
\hline 1912 & 1913 \\
\hline $\begin{array}{r}7 \\
\text { I0I.0 } \\
809.0 \\
8.01\end{array}$ & $\begin{array}{c}21 \\
262.8 \\
1,659.5 \\
6.31\end{array}$ \\
\hline $\begin{array}{r}\$ 33.00 \\
31.27 \\
\text { I. } 73\end{array}$ & $\begin{array}{r}\$ 26.04 \\
-\quad 32.59 \\
\end{array}$ \\
\hline $\begin{array}{r}\$ 4.12 \\
3.90 \\
0.22\end{array}$ & $\begin{array}{r}\$ 4.12 \\
5.16 \\
-1.04\end{array}$ \\
\hline$\$ 0.05$ & - $-\$ 0.16$ \\
\hline $\begin{array}{l}37.4 \\
52.9 \\
\ldots . .\end{array}$ & $\begin{array}{r}41.8 \\
59.4 \\
* 325 .\end{array}$ \\
\hline
\end{tabular}

* Average for the I4 farms that used commercial fertilizer on corn.

Weather conditions in 1912 were favorable for the production of corn, and the yield was 8.o I tons per acre. On September 8, I9I3, there was a hard freeze throughout most of New York State. Few fields of corn had been cut at that time and the crop was heavily damaged. This accounts for the low yield of 6:3 I tons per acre for I9I3.

The best yicld of silage corn for the two years was i I tons per acre. One farm had a yield as low as 3.29 tons per acre. Four farms in 1912 and five in I9I3 produced silage corn for less than $\$ 4$.I2 a ton.

The average distribution of the cost of raising silage corn is shown in table I 5 . 
TABLE 15. AVERAGi: DISTRIBT TIUN OF COAT OF PRODUCING SILAGE CORN

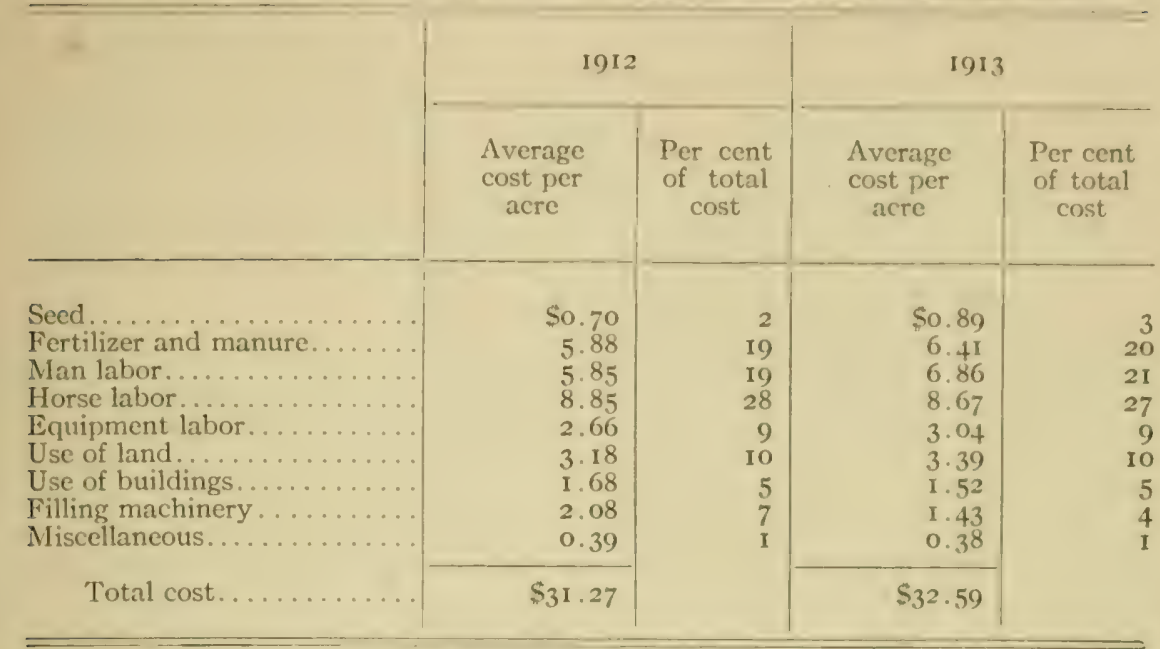

The labor cost of raising silage corn is about $5^{6}$ per cent of the total cost. The next most important costs are for fertilizer and manure, which amount to about 20 per cent of the total, and use of land, which is 10 per cent of the total. The cost for use of buildings was estimated high enough to cover interest and annual depreciation on the silo. This charge is higher than the charge for buildings of the same value used by other crops, for the annual depreciation on silos is higher than on barns. The cost of twine for binding the silage corn is included under Miscollaneous.

Table i6. Average Cost of Producing Silage Corn up to the Time of HARVESTING

$\sec 1$

Fertilizer and manure

Man labor.

Horse labor

Equipment labor. . . . . . . . . . . . . . . . . . . . . . . .

Use of land.

Total cost

(3)

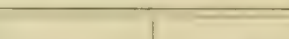

\begin{tabular}{|c|c}
\hline 1912 & 1913 \\
\hline Cost & Cost
\end{tabular}
per acre per acre

Man hours

Horse hours 
The cost of raising the corn, and the cost of harvesting and putting the corn in the silo, were separated. The point of separation was after the last cultivation. All work and expense before this was considered a part of the cost of production. The labor of harvesting the corn and filling the silo, the use of the silo-filling machinery, the twine, and the use of the silo, were considered in the cost of harvesting. The distribution of the cost up to the time of harvesting is shown in table 16 , and of harvesting in table 17 :

table 17. Average Cost of Harvesting Silage Corn and of Filling Silo, INCLUDING USE OF SILO

\begin{tabular}{|c|c|c|c|c|}
\hline & \multicolumn{2}{|c|}{1912} & \multicolumn{2}{|c|}{ I913 } \\
\hline & $\begin{array}{l}\text { Cost } \\
\text { per acre }\end{array}$ & $\begin{array}{l}\text { Cost } \\
\text { per ton }\end{array}$ & $\begin{array}{l}\text { Cost } \\
\text { per acre }\end{array}$ & $\begin{array}{l}\text { Cost } \\
\text { per ton }\end{array}$ \\
\hline 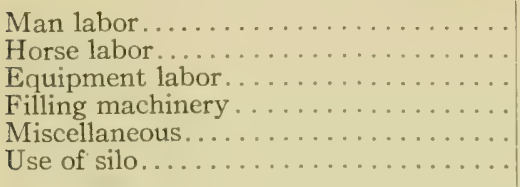 & $\begin{array}{r}\$ 2.13 \\
2.79 \\
0.88 \\
2.08 \\
0.39 \\
\text { I. } 68\end{array}$ & $\begin{array}{l}\$ 0.26 \\
0.35 \\
0.1 \text { I } \\
0.26 \\
0.05 \\
0.21\end{array}$ & $\begin{array}{r}\$ 2.78 \\
2.40 \\
\text { I. } 16 \\
\text { 1. } 43 \\
0.38 \\
\text { I. } 52\end{array}$ & $\begin{array}{l}\$ 0.44 \\
0.38 \\
0.18 \\
0.23 \\
0.06 \\
0.24\end{array}$ \\
\hline Total cost. . . . . . . . . . & $\$ 9.95$ & $\$ 1.24$ & $\$ 9.67$ & $\$ 1.53$ \\
\hline $\begin{array}{l}\text { Man hours. . . . . . . . . . . . . . . . . } \\
\text { Horse hours } \ldots \ldots \ldots \ldots \ldots\end{array}$ & $\begin{array}{l}14.33 \\
16.88\end{array}$ & $\begin{array}{l}\text { I. } 79 \\
\text { 2. I I }\end{array}$ & $\begin{array}{l}\text { I6. } 8 \\
\text { I6. II }\end{array}$ & $\begin{array}{l}2.66 \\
2.55\end{array}$ \\
\hline
\end{tabular}

Over one-third of the total labor on silage corn is spent in harvesting the corn and filling the silo.

In Farmers' Bulletin 578 of the United States Department of Agriculture, the cost of filling the silo is placed at $8_{7}$ cents a ton. This figure, however, does not include use of ordinary equipment, use of silo, or use of silo-filling machinery. If the figures given in table ${ }_{7} 7$ for these items are added to the 87 cents a ton, the result checks very closely with the total cost per ton as given in the table.

\section{POTATOES}

In I9I2 and I9I3 potatoes were raised on every cooperating farm. Many of the farmers, however, raised potatoes only on small acreages, for home use. Only fields of two acres or more were used in the tabulation.

The average yield of potatoes for the farms studied was 102.49 bushels in 1912 and 102.66 bushels in I9I3. The average yield for the State was rof bushels in I9I2 and 74 bushels in I9r $3 .^{7}$ The highest yield (1) Hainer in the two years on the farms studied was 230 bushels an acre, while on three farms the yield was less than 50 bushels an acre.

7 U. S. Agr. Dept. Yearbook 1913: 412. 
The data concerning the production of potatoes are given in table is: TABLE 18. Averages for Potatoes

\begin{tabular}{|c|c|c|}
\hline & 1912 & I9I3 \\
\hline 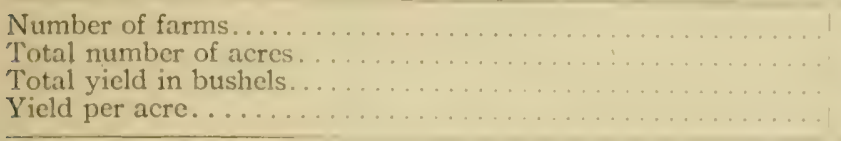 & $\begin{array}{r}8 \\
57 \cdot 5 \\
5,893 \cdot 0 \\
102.49\end{array}$ & $\begin{array}{r}18 \\
185 \cdot 4 \\
19,032.8 \\
102.66\end{array}$ \\
\hline $\begin{array}{l}\text { Value per acre } \ldots \ldots \ldots \ldots \ldots \\
\text { Cost per acre } \ldots \ldots \ldots \ldots \\
\text { Profit or loss per acre } \ldots \ldots \ldots \ldots \ldots\end{array}$ & $\begin{array}{r}\$ 55.28 \\
64.88 \\
-\quad 9.60 \\
\end{array}$ & $\begin{array}{r}\$ 6.09 \\
56.71 \\
7.38\end{array}$ \\
\hline 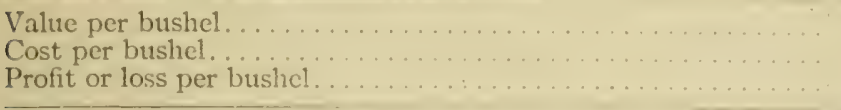 & $\begin{array}{r}50.54 \\
0.63 \\
-0.09\end{array}$ & $\begin{array}{r}\$ 0.62 \\
0.55 \\
0.07\end{array}$ \\
\hline Profit or loss per man hour. & -50.09 & So. 08 \\
\hline 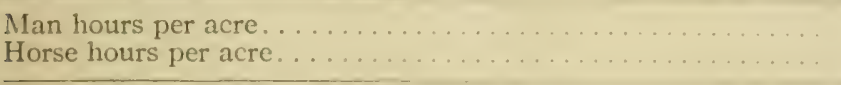 & $\begin{array}{l}101.53 \\
102.26\end{array}$ & $\begin{array}{l}88.1 \text { I } \\
8+.50\end{array}$ \\
\hline 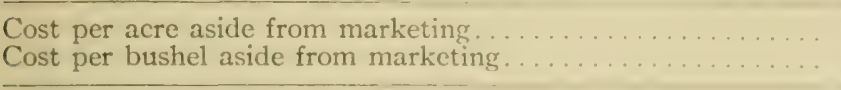 & & $\begin{array}{r}\$ 53.74 \\
0.52 \\
\end{array}$ \\
\hline $\begin{array}{l}\text { Man hours per acre aside from marketing. ........ } \ldots \ldots \ldots \\
\text { Horse hours per acre aside from marketing . } \ldots \ldots \ldots \ldots \ldots \\
\text { Pounds of commercial fertilizer per acre } \ldots \ldots \ldots \ldots \ldots \ldots\end{array}$ & & $\begin{aligned} & 77.68 \\
& 77 \cdot 35 \\
& 522\end{aligned}$ \\
\hline
\end{tabular}

* Average for the 12 farms that used commercial fertilizer on potatoes.

The average distribution of the cost of raising potatoes is shown in table I9:

TABle 19. Average Distribution of Cost of Producing Potatoes

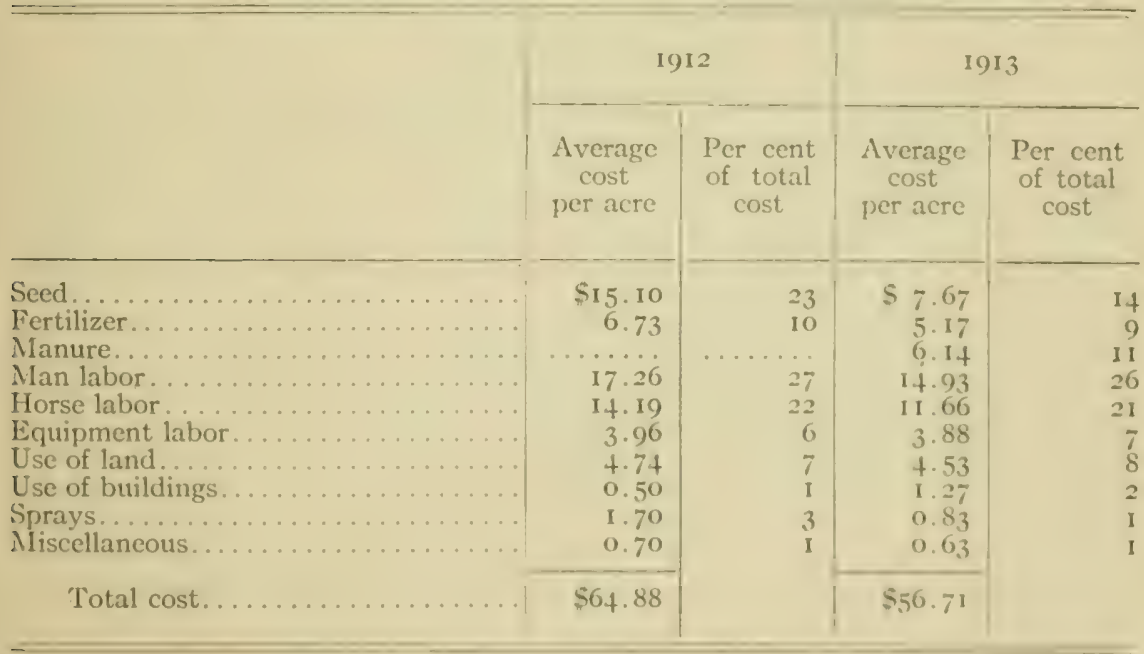


Fluctuation in the value of seed constitutes a large part of the yearly fluctuation in the cost per acre of raising potatoes. Seed potatoes were much higher in 1912 than in 1913. The average amount of seed used per acre was Iо.оI bushels in I9I3.

One farmer used about 2000 pounds of commercial fertilizer per acre. No other farmer used more than 635 pounds per acre.

In I9I 2 two farmers, and in I9I3 five farmers, did not spray potatoes. The highest cost of spray materials per acre was $\$ 3.75$.

On six farms in I9I 2 and on three in I9I3 no potatoes were stored and consequently there was no charge for use of buildings on these farms. One farmer had a charge of $\$ 3.33$ per acre for use of buildings.

In I9I 3 the cost of producing potatoes was separated from the cost of marketing. Many potatoes were not marketed until after the accounts were closed. For this reason, the costs of marketing are for a smaller number of total bushels than were produced. The data concerning the cost of marketing potatoes in I9I3 are given in table 20 :

table 20. Cost of Marketing Potatoes, i913

Number of farms

Number of bushels of potatoes
Man hours per bushel................

I I

4,55 I

Han hours per bushel...

0.43

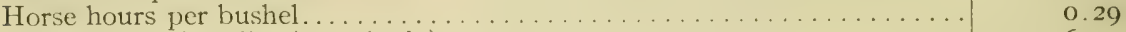

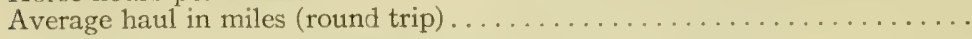

6.3

Man labor cost per bushel

$\$ 0.07$

Horse labor cost per bushel.

0.04

Equipment labor cost per bushel

0.01

Total cost per bushel.

\$o. 12

\section{OTHER CROPS}

Tabulations were made for several other crops in I9I3. The number of farms used in each tabulation is small, and weather conditions that year were exceptionally poor for the production of some crops. For these reasons only a few factors are given. These are presented in table $2 \mathrm{I}$.

Alfalfa.- On three farms alfalfa was produced in fields of 2 acres or more. On one of these there were 7.5 acres in alfalfa, on another 28 acres, and on the third 67 acres. These farms were located on limestone soil in the central part of the State, in regions where alfalfa does exceptionally well. The average yield per acre on these farms was 3.34 tons; the average yield for New York State was 2.33 tons in 1899 and 2.46 tons in I (jo) ${ }^{8}$ The number of man hours and of horse hours per

\&Warren, fr. F. Croy yields and prices, and our future food supply. Cornell Univ. Agr. Exp. Sta. Bul. 341 : 191 . 
acre seem to be alout normal. The amount charged for use of land indicates the high value of the land on which alfalfa is produced. These factors may be typical for alfalfa grown on the better farms in the best alfalfa sections of New York State in favorable years.

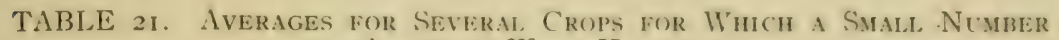
OF ACCOUNTS Were Kept, I9I3

\begin{tabular}{|c|c|c|c|c|c|c|}
\hline & Alfalfa & Barley & Bcans & $\begin{array}{l}\text { Buck- } \\
\text { wheat }\end{array}$ & Cabbage & Wheat \\
\hline $\begin{array}{l}\text { Number of farms..... } \\
\text { Number of acres.... } \\
\text { Yield per acre..... }\end{array}$ & $\begin{array}{l}3 \\
102.5 \\
3.34 \text { tons }\end{array}$ & $\begin{array}{l}3 \\
43 \\
3 \mathrm{I} .9 \mathrm{bu} .\end{array}$ & $\begin{array}{l}2 \\
83 \\
9 \\
\text { bu. }\end{array}$ & $\begin{array}{l}7 \\
75.6 \\
14 \mathrm{bu} .\end{array}$ & $\begin{array}{l}\stackrel{4}{28.6} \\
5.2 \text { tons }\end{array}$ & $\begin{array}{l}5 \\
3^{8} \\
27 \cdot+\mathrm{bus}\end{array}$ \\
\hline $\begin{array}{l}\text { Value per acre........ } \\
\text { Cost per acre......... } \\
\text { Profit or loss per acre. }\end{array}$ & $\begin{array}{r}\$ 53 \cdot 37 \\
20.02 \\
33 \cdot 35\end{array}$ & $\begin{array}{r}\$ 24.88 \\
26.97 \\
-\quad 2.09\end{array}$ & $\begin{array}{r}\$ 27.28 \\
24.58 \\
2.70\end{array}$ & $\begin{array}{r}\$ 12.2 I \\
18.52 \\
-\quad 6.3 I\end{array}$ & $\begin{array}{r}\$ 105.77 \\
45.64 \\
60.13\end{array}$ & $\begin{array}{r}\$ 29.98 \\
29.17 \\
0.81\end{array}$ \\
\hline $\begin{array}{l}\text { Man hours per acre... } \\
\text { Horse hours per acre.. }\end{array}$ & $\begin{array}{l}28.56 \\
23.95\end{array}$ & $\begin{array}{l}34.74 \\
50.46\end{array}$ & $\begin{array}{l}31.73 \\
+.4 .60\end{array}$ & $\begin{array}{l}20.35 \\
37 \cdot 46\end{array}$ & $\begin{array}{l}90.92 \\
73.43\end{array}$ & $\begin{array}{l}23.67 \\
41.47 \\
\end{array}$ \\
\hline $\begin{array}{l}\text { Cost of use of land per } \\
\text { acre............. }\end{array}$ & $\$ 7.39$ & $\$ 4.99$ & $\$ 4.33$ & $\$ 2.53$ & $\$ 5.20$ & $\$ 3.95$ \\
\hline
\end{tabular}

Barley.- Barley was produced on three farms. The average yield was 31.9 bushels per acre; the arerage yield for New York State in I9I 3 was 26.7 bushels per acre. ${ }^{9}$ The number of man hours and of horse hours, and the cost per acre, seem too high when compared with the average cost of producing oats.

Beans.-A heavy freeze on September I5, I9 13, seriously injured the bean crop of New York State. The average yield of beans on the two farms for which results are given was only o bushels per acre. The average yicld for New Tork State in Inon was 1.4 .5 bushels. ${ }^{10}$

Buckwheat. - Buckwheat was produced on seven farms. This crop) also was seriously injured by the freeze of September 15. The arerage yield for these seven farms was it bushels per acre. The arerage yicld per acre for the whole State was 14.3 bushels in 19 I 3 , and was is.8 bushels per acre for the ten years from I900 to I909. ${ }^{11}$

Cabbage. - The year 1013 was unfavorable for the growth of cablage. The arerage yickl on the four farms tabulated was 5.2 tons per acte. This is a little more than half the nomal yield. The price received per ton was more than enough to make up for the low yield, and the profit per

U. S. Agr. Dept. Yearbook 1913: 397.

10 Thirteenth Census of the United States $7: 2$ I0. I9ro.

11 U. S. Agr. Dept. Yearbook 1913: 407. 
acre was abnormally high. The man hours and the horse hours per acre, and the cost per acre, were probably lower than the normal because of the small tonnage harvested.

Wheat.- The wheat tabulation included five farms with 38 acres. The average yicld was 27.4 bushels per acre; the average yield for the State was 20 bushels per acre for I9I 3 , and was 17.4 bushels for the ten years from 1900 to $1909 .{ }^{12}$ The number of man hours and of horse hours per acre, and the cost per acre, were probably too high to be typical.

\section{DAIRY COWS}

Dairy cows are the most important livestock kept on New York farms. Seven farms in I9I2, and twenty-two farms in I9I3, had herds of five or more cows and were used in the tabulations. The herds on one of these farms in I9I 2 and on five in I9I3 were purebreds. All these cattle were of the Holstein-Friesian breed, which was also the predominating breed among the grade cattle.

The principal products sold from the dairy farms were milk and stock. Milk was sold largely as market milk, to be shipped to the large cities. Small quantities of cream, butter, creamery milk, and cheese factory milk, were sold.

Most of the results were calculated on the cattle unit basis. One cow, one bull, or two head of young stock, were counted as one cattle unit. The smallest herd used in the tabulations had an average of 5.5 cows; the largest herd averaged 40.5 cows. Both these herds showed a profit. The data are given in table 22 . The results of the dairy accounts for I9I2 and 1913 are summarized in tables 23 and 24 , respectively.

TABLE 22. Dairy Cows

\begin{tabular}{|c|c|c|c|c|}
\hline & \multicolumn{2}{|c|}{ I912 } & \multicolumn{2}{|c|}{1913} \\
\hline & Grades & Purebreds & Grades & Purebreds \\
\hline 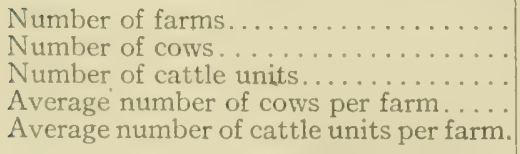 & $\begin{array}{l}6 \\
\text { I I I.0 } \\
\text { I } 74.2 \\
\text { I } 8.5 \\
29.03\end{array}$ & $\begin{array}{l}\text { I } \\
\text { I } 8.5 \\
25.0 \\
\text { I } 8.5 \\
25.00\end{array}$ & $\begin{array}{l}17 \\
297.5^{\circ} \\
406.33 \\
17.5 \\
23.90\end{array}$ & $\begin{array}{c}5 \\
110.5 \\
163.75 \\
22.1 \\
32.75\end{array}$ \\
\hline $\begin{array}{l}\text { Average value per cow. .............. } \\
\text { Average value per cattle unit......... }\end{array}$ & $\begin{array}{r}\$ 72.23 \\
70.14\end{array}$ & $\begin{array}{r}\$ 211.49 \\
201.00\end{array}$ & $\begin{array}{r}\$ 71 \cdot 10 \\
67 \cdot 32\end{array}$ & $\begin{array}{r}\$ 215.90 \\
224.10\end{array}$ \\
\hline
\end{tabular}

12 U. S. Agr. Dept. Yearbook 1913: 382. 
TABLE 23. Summary OF Results of Darry ACCOUNTS For 1912

\begin{tabular}{|c|c|c|c|c|c|c|}
\hline \multirow[t]{2}{*}{$=$} & \multicolumn{3}{|c|}{ Grade herds } & \multicolumn{3}{|c|}{ Purebred herds } \\
\hline & Total & $\begin{array}{l}\text { Per } \\
\text { cattle } \\
\text { unit }\end{array}$ & $\begin{array}{l}\text { Per } \\
\text { cent of } \\
\text { total }\end{array}$ & Total & $\begin{array}{l}\text { Per } \\
\text { cattle } \\
\text { unit }\end{array}$ & $\begin{array}{l}\text { Per } \\
\text { cent of } \\
\text { total }\end{array}$ \\
\hline \multicolumn{7}{|c|}{ Costs } \\
\hline Forage (except silage). & $\$ 2,298.85$ & $\$ 13.20$ & 16 & $38+\cdot 45$ & $\$ 15.38$ & 12 \\
\hline Bedding................ & 268.50 & I. 54 & 2 & 53.06 & 2.12 & 2 \\
\hline Silage............. & $2,509.70$ & $14 \cdot 4 \mathrm{I}$ & 18 & 603.00 & 24.12 & 18 \\
\hline Grain ............... & $3,431.89$ & 19.70 & 24 & $1,017,13$ & 40.68 & 31 \\
\hline Pasture.......... & I,, 000.00 & $5 \cdot 74$ & 7 & 50.00 & 2.00 & 2 \\
\hline $\begin{array}{l}\text { Veterinary fees and } \\
\text { medicine.......... }\end{array}$ & 35.47 & 0.20 & , & $12-70$ & & \\
\hline Man labor.............. & $\begin{array}{r}35 \cdot 47 \\
2,921 \cdot 37\end{array}$ & 16.77 & $2 I$ & $\begin{array}{r}43.79 \\
645.73\end{array}$ & $\begin{array}{r}\text { I. } 75 \\
25.83\end{array}$ & ${ }_{20}^{1}$ \\
\hline Horse labor.......... & 425.31 & 2.44 & 3 & 58.85 & $\begin{array}{r}-3.03 \\
2.35\end{array}$ & 2 \\
\hline Equipment labor..... & 144.38 & 0.83 & I & 14.71 & 0.59 & . \\
\hline Use of buildings. ..... & 378.00 & 2.17 & 3 & 80.00 & 3.20 & 2 \\
\hline Interest............ & 613.67 & $3 \cdot 5^{2}$ & 4 & 25 I. 25 & 10.05 & 8 \\
\hline Miscellaneous........ & 203.63 & 1.17 & I & 70.66 & 2.83 & 2 \\
\hline Total cost...... & $\$ 14,230.77$ & $\$ 81.69$ & $\cdots$ & $\$ 3,272.63$ & $\$ 130.90$ & $\cdots$ \\
\hline \multicolumn{7}{|l|}{ Returns } \\
\hline Manure............... & $\$ I, 475.50$ & $\$ 8.47$ & $\ldots \ldots$ & $\$ 120.00$ & $\$ 4.80$ & $\ldots \ldots$ \\
\hline $\begin{array}{r}\text { Milk - per grade cow, } \\
\$ 82.88 \ldots\end{array}$ & $9,200.26$ & (1) & & $\ldots \ldots$ & $\ldots$ & $\ldots \ldots$ \\
\hline $\begin{array}{l}\text { Milk - per purebred } \\
\text { cow, \$92.16.......... } \\
\text { Cattle increase and net }\end{array}$ & & & & $1,704.91$ & & \\
\hline 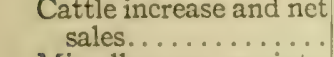 & $3,598.34$ & 20.66 & & $2,487.26$ & 99.49 & ...... \\
\hline Miscellaneous receipts. & 31.55 & 0.18 & $\ldots \ldots$ & $\ldots \ldots \ldots$ & $\ldots \ldots$ & $\ldots \ldots$ \\
\hline Total returns. . & $\$ 14,305.65$ & $\$ 82.12$ & $\ldots \ldots$ & $\$ 4.312 .17$ & $\$ 172.49$ & $\ldots \ldots$ \\
\hline Profit. & $\$ 74.88$ & \$o. 43 & $\ldots \ldots$ & $\$ 1,039.54$ & $\$ 41.59$ & $\cdots$ \\
\hline
\end{tabular}

The total cost of keeping a cattle unit of grale stock was $\$ S$ r.69 in in 12 , and $\$ 92.0 \mathrm{r}$ in 1913 ; the total cost of keeping a cattle unit of purchred stock was $\$$ I30.90 in I9I2, and $\$$ I $39.90 \mathrm{in}$ igr3. Crade cows produced milk to the value of $\$ S_{2} . S S_{\text {per }}$ cow in Ior 2 , and $\$ 99.47$ per cow in Ior 3 ; the value of the milk produced by purebreds was $\$() 2.16$ per cow in Io I 2 , and $\$ 107.72$ per cow in I9I3.

The greatest difference in returns from grade and purebred stock was in the cattle increase and net sale. This factor was found by adding together the last cattle inventory and the cattle sold, and subtracting from this total the sum of the first cattle inventory and the cattle purchased. Cattle increase and net sales for grade stock amounted to $\$ 20.66$ per cattle unit in 1912 , and $S_{1} 8.02$ per cattle unit in 1913 ; for purebred stock this item was $\$ 99.49$ per cattle unit in I912, and $\$ S_{7.00}$ per cattle unit in I9 13 . 
TABlE 24. Sumiry OF Results of Dairy Accounts for 1913

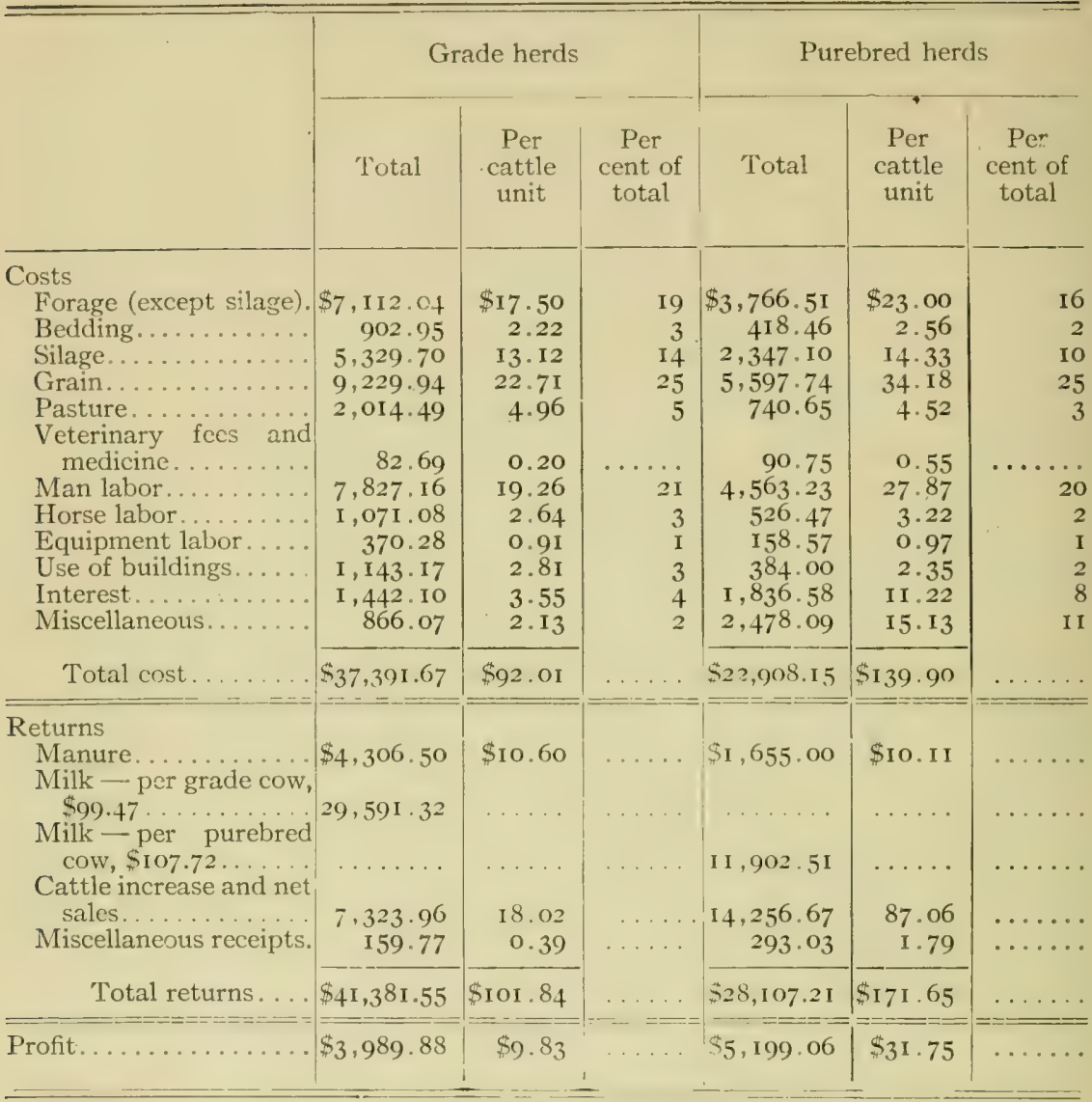

The total returns per cattle unit for grade stock were $\$ 8_{2} .12$ in 1912 , and \$ror.84 in I9I3; for purebreds this figure amounted to $\$ 172.49$ in 1912, and $\$$ I7I.65 in I9I3. The profit per cattle unit on grade cattle was 43 cents in I9I 2 , and $\$ 9 . S_{3}$ in I9I3; on purebreds it was $\$ 41.59$ in I9I2, and $\$ 31.75$ in 1913 .

The total food and bedding cost per cattle unit for grade stock was $\$ 54.59$ in I9I2, and $\$ 60.5 \mathrm{I}$ in I9I3; for purebreds it was $\$ 84.30$ in I9I2,

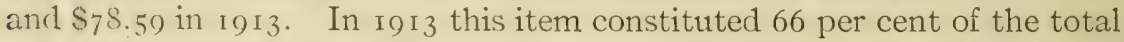
cost of kecping grade cattle, and 56 per cent of the cost of keeping purebred cattle.

The man labor charge was much higher for purebreds than for grade stock. The charges for veterinary service and medicine, and for interest, were also higher for purebred than for grade cattle. 
The average quantities of feed given the herds, the amount of labor required for their care, and the amount of milk produced, are given in table 25:

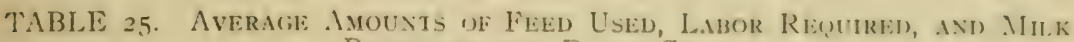
Produced, For Datry Cows

Pounds of straw for feed and bedding per cattle unit................

Pounds of other forage per cattle unit.

Pounds of grain per cattle unit........

Man hours per cattle unit.

Horse hours per cattle unit.

Pounds of milk per cow

\begin{tabular}{|c|c|c|c|}
\hline \multicolumn{2}{|c|}{1912} & \multicolumn{2}{|c|}{1913} \\
\hline $\begin{array}{l}\text { Grade } \\
\text { cows }\end{array}$ & $\begin{array}{l}\text { Pure- } \\
\text { breds }\end{array}$ & $\begin{array}{l}\text { Grade } \\
\text { cows }\end{array}$ & $\begin{array}{l}\text { Pure- } \\
\text { breds }\end{array}$ \\
\hline 617 & I60 & 779 & 798 \\
\hline${ }^{*} 6,1,52$ & 10.320 & 6.7 .37 & $6,-7) 1$ \\
\hline${ }^{*} 1,865$ & 2,800 & 3,190 & 3,216 \\
\hline 1,313 & 2,660 & I. $55 \mathrm{I}$ & 2,339 \\
\hline 117 & 130 & 116 & 161 \\
\hline 13 & 19 & 19 & 23 \\
\hline & & 17,926 & $\ddagger 8.222$ \\
\hline
\end{tabular}

* One farm did not feed silage and was omitted frcm this average.

$\dagger$ Average for 13 out of 17 herds.

\pm Average for 2 out of 5 herds.

It is shown in table 25 that purebred cattle were fed more than grade cattle, and more man hours and more horse hours were required to care for a cattle unit of purebreds than for a cattle unit of grade stock. Purebreds gave more milk per cow than did grade stock.

It should be observed that the grade cows on the cooperating farms were much better than the average New York State cow. The grade herds in the 1913 tabulation produced an average of 7926 pounds of milk jer cow, whereas the average production per cow for the State was 4463 pounds in $1909 .{ }^{13}$

\section{DISTRIBUTION OF LABOR BY ENTERPRISES}

All labor was first classified under labor fixed as to scason, and lahor not fixed as to season. Plowing, hauling fertilizer, threshing, and cleaning seed, were considered as labor not fixed as to season. Fitting the groumel. planting, harvesting, cultivating, spraying, and rolling, were considered as lahor fixed as to season. Marketing was not incluted in any of the tables. Wrork on cows was all considered as fixed lahur. This was separated into labor on chores or other werk, and milk hatuling.

13 Thirteenth Census of the United States 7:205. 1910. 
All labor was classified also by ten-days periods, each month being divided into three periods. From the ist day of the month to the ioth, inclusive, was called the first period; from the inth to the 2 oth day, inclusive, was called the second period; from the $2 \mathrm{Ist}$ to the last day of the month, inclusive, was called the thir 1 period.

Probably a greater proportion of fall plowing was done than is indicated by the tables. The year I9I3 was the first year for which accounts were kept on several of the farms. Data from some farms could not be used in these tabulations, because fall plowing had been done, of which there was no record.

Only those farms were used in the tabulations that had a growing season typical of central New York. Farms from the extreme north or south of the State were not used. The data for man labor are contained in tables 26 (०) $3 \div$, inclusive, and the data for horse labor in tables 32 to 36 , inclusive. 
TABIE 26. Distribution of Man Labor per Acre on Timotiry and Clover biy Operations and by Ten-Days Periods. Fifteen Farms, 662.9 ACres, 1913

\begin{tabular}{|c|c|c|c|c|}
\hline Month & I'eriod & $\begin{array}{l}\text { Hours } \\
\text { of labor } \\
\text { fixed } \\
\text { as to } \\
\text { season* }\end{array}$ & $\begin{array}{l}\text { Hours of } \\
\text { labor not } \\
\text { fixed as } \\
\text { to season* }\end{array}$ & $\begin{array}{l}\text { Total } \\
\text { number } \\
\text { of hours }\end{array}$ \\
\hline January............... & $\begin{array}{l}1 \\
2 \\
3\end{array}$ & & .111 & 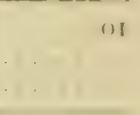 \\
\hline Fobruary. & $\begin{array}{l}1 \\
2 \\
.3\end{array}$ & & & \\
\hline$\bullet$ & $\begin{array}{l}\text { I } \\
2 \\
3\end{array}$ & $\ldots \ldots \ldots$ & . in & ii \\
\hline April ...... & $\begin{array}{l}1 \\
2 \\
3\end{array}$ & . & $\begin{array}{l}.05 \\
.01 \\
.02\end{array}$ & $\begin{array}{l}.05 \\
.01 \\
.02\end{array}$ \\
\hline May.......... & $\begin{array}{l}\mathrm{I} \\
2 \\
3\end{array}$ & & $\begin{array}{r}\text { OI } \\
\text { OI } \\
\text { OI }\end{array}$ & 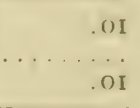 \\
\hline June.................. & $\begin{array}{l}\text { I } \\
2 \\
3\end{array}$ & $\begin{array}{r}\ldots \ldots \\
\text { I3 } 3\end{array}$ & $\begin{array}{r}.02 \\
.02 \\
.0 . \ldots \\
\end{array}$ & $\begin{array}{l}.02 \\
.02 \\
.13 \\
\end{array}$ \\
\hline n......... & $\begin{array}{l}\text { I } \\
2 \\
3\end{array}$ & $\begin{array}{l}1.72 \\
3.78 \\
3.01\end{array}$ & $\begin{array}{l}\ldots \ldots \\
\cdots \cdots\end{array}$ & $\begin{array}{l}1.72 \\
3.78 \\
3.01\end{array}$ \\
\hline Avigust . . . . . . . . . . & $\begin{array}{l}\text { I } \\
2 \\
3\end{array}$ & .84 & $\ldots \ldots$ & $8_{4}$ \\
\hline September........... & $\begin{array}{l}1 \\
2 \\
3\end{array}$ & $\ldots \ldots$ & of & ai \\
\hline Octoher. & $\begin{array}{l}1 \\
2 \\
3\end{array}$ & $\begin{array}{l}\ldots \ldots \ldots \\
\ldots \ldots \ldots \\
\ldots \ldots \\
\end{array}$ & $\begin{array}{l}02 \\
01\end{array}$ & $\therefore 2$ \\
\hline Total. & & 9.48 & .28 & 9.76 \\
\hline
\end{tabular}

* The fixed labor was all harvesting. The labor not fixed was seeding, rolling, and other miscellaneous operations. 


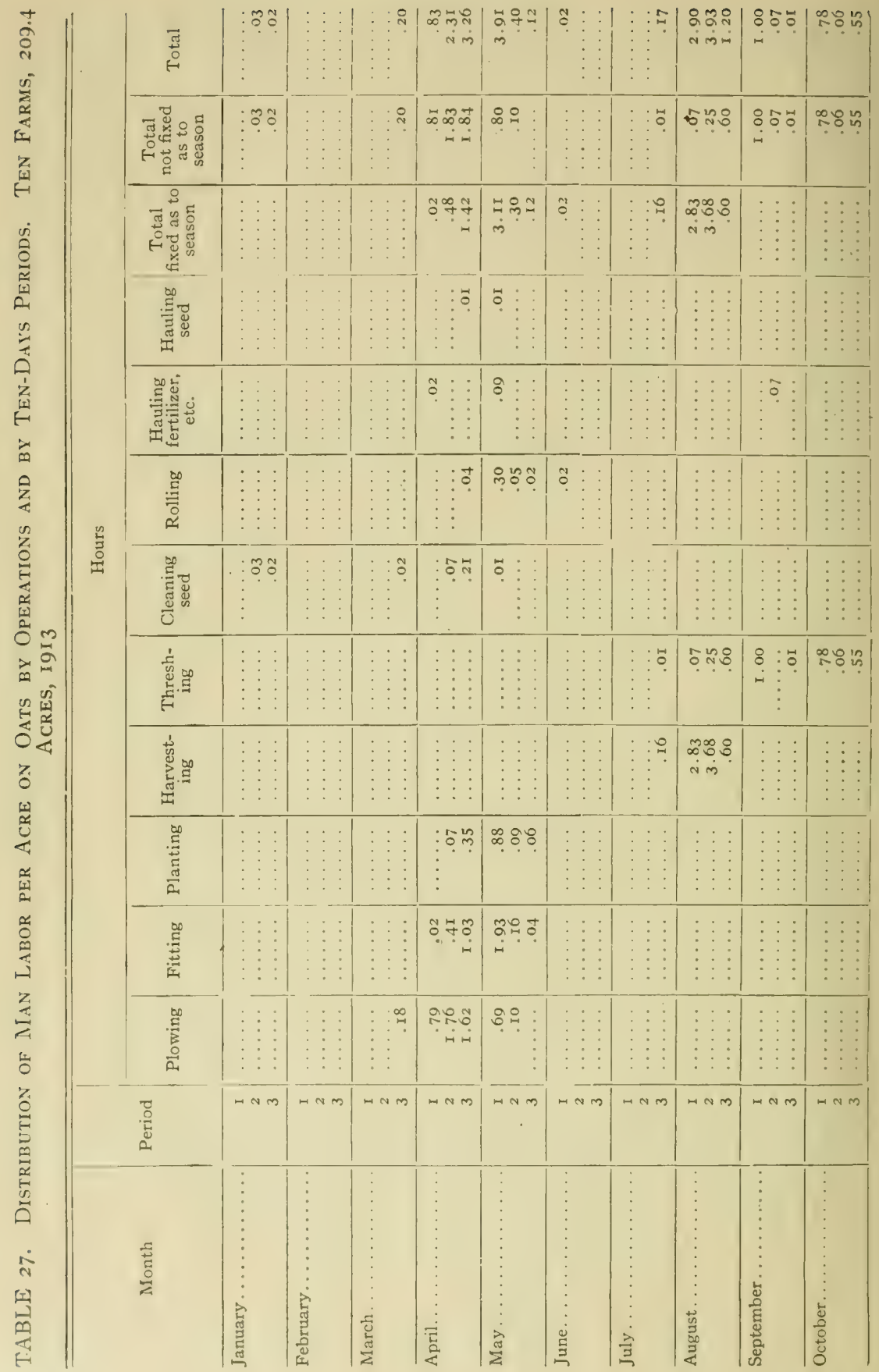


Cost Accounts on Some New York Farms

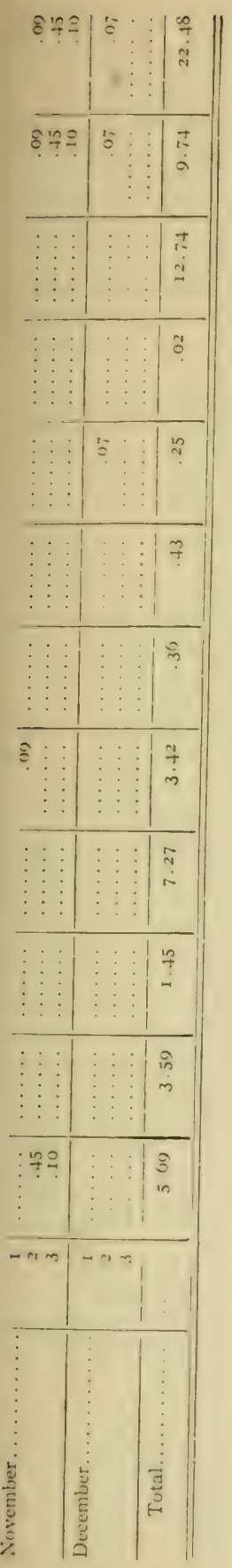




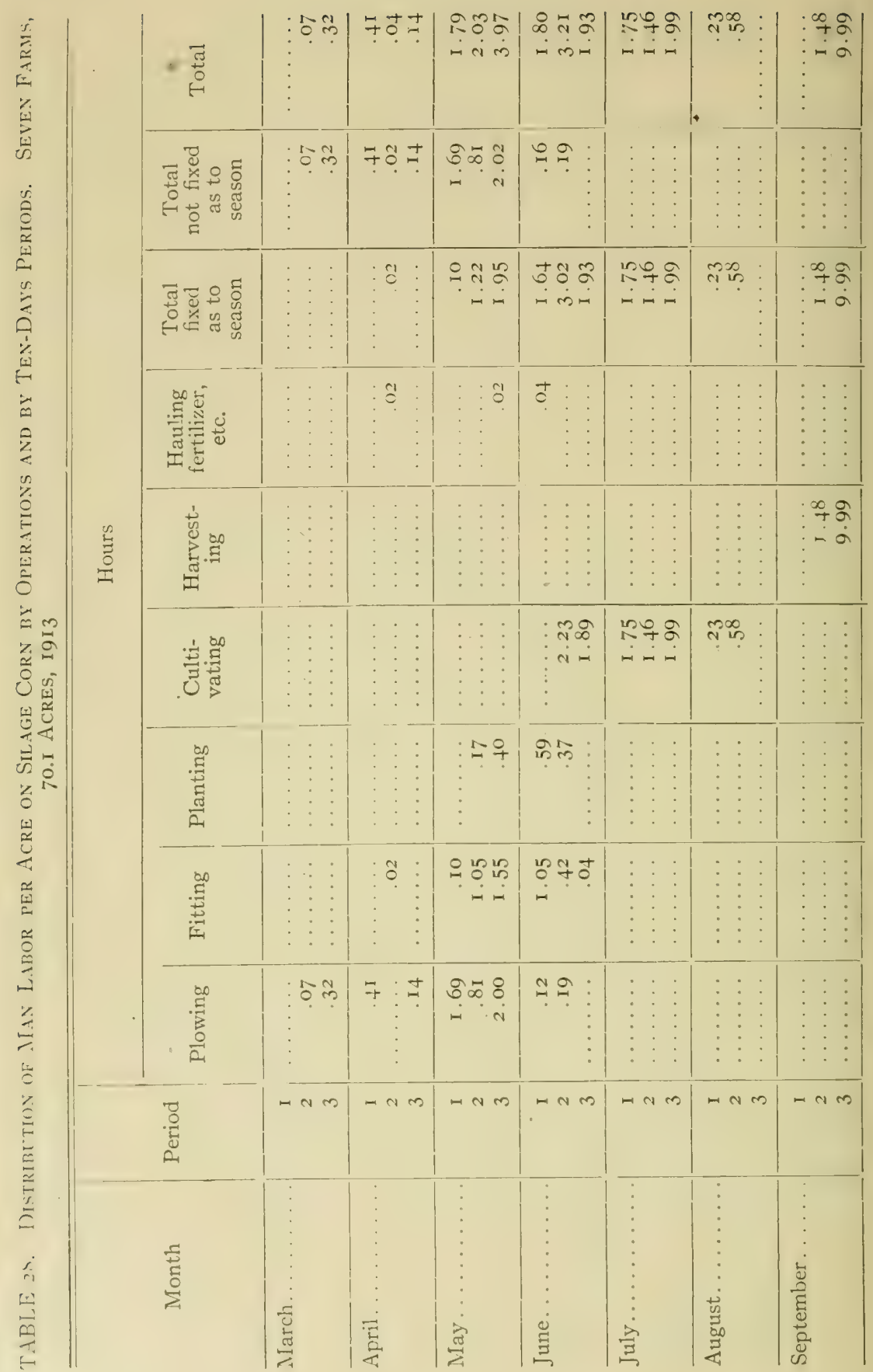




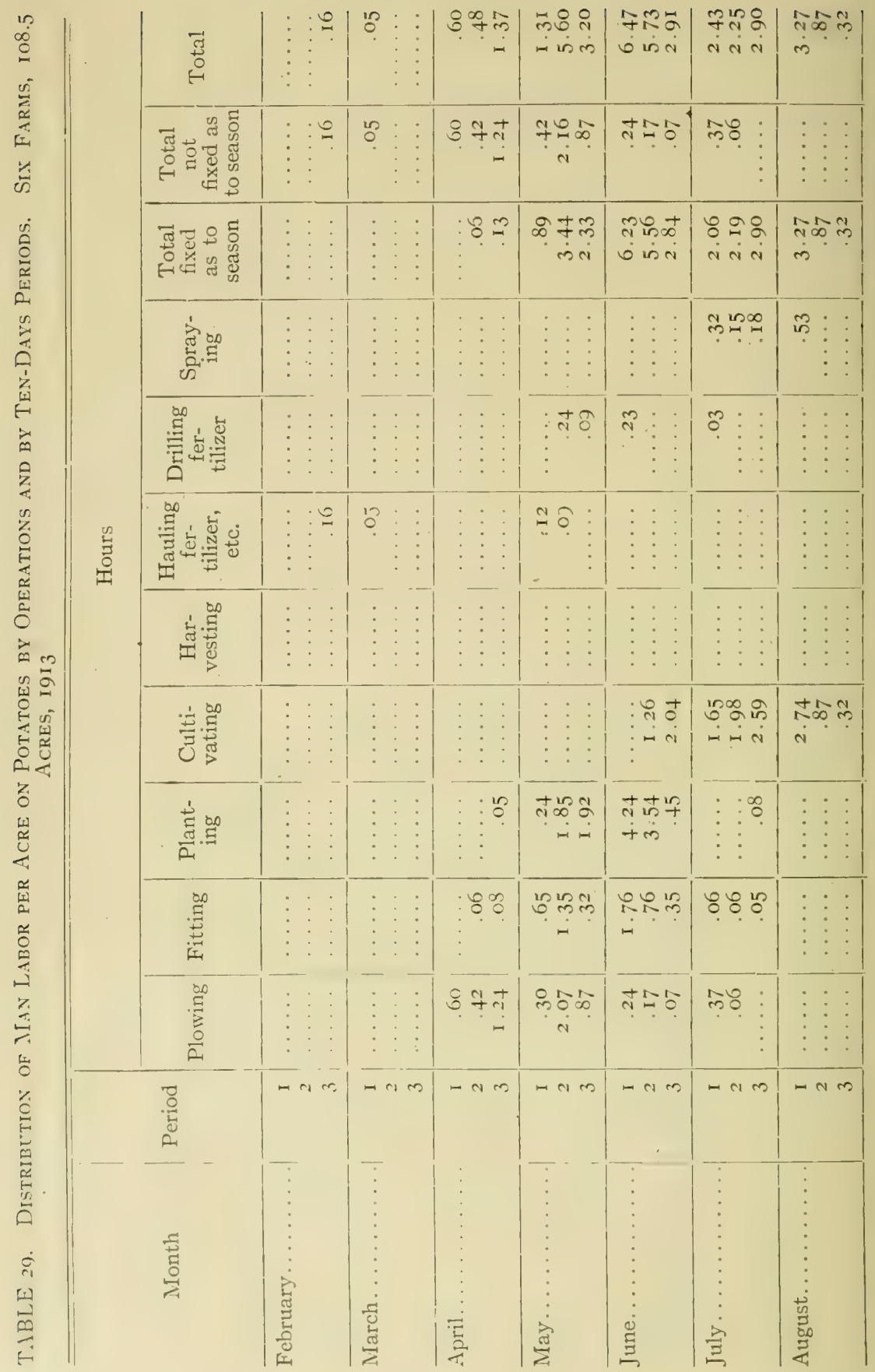


Cost Accounts on Some New York liakns

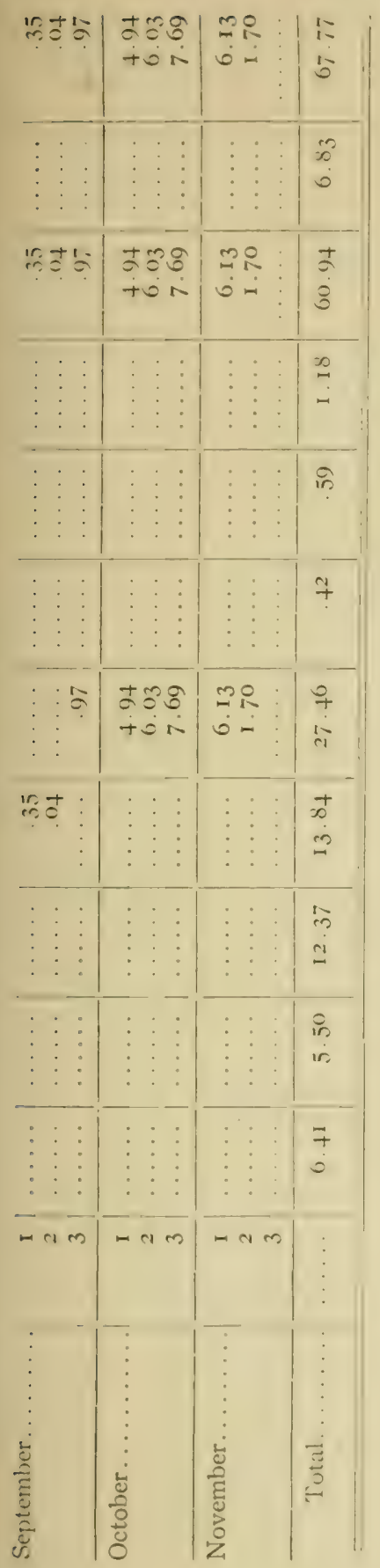




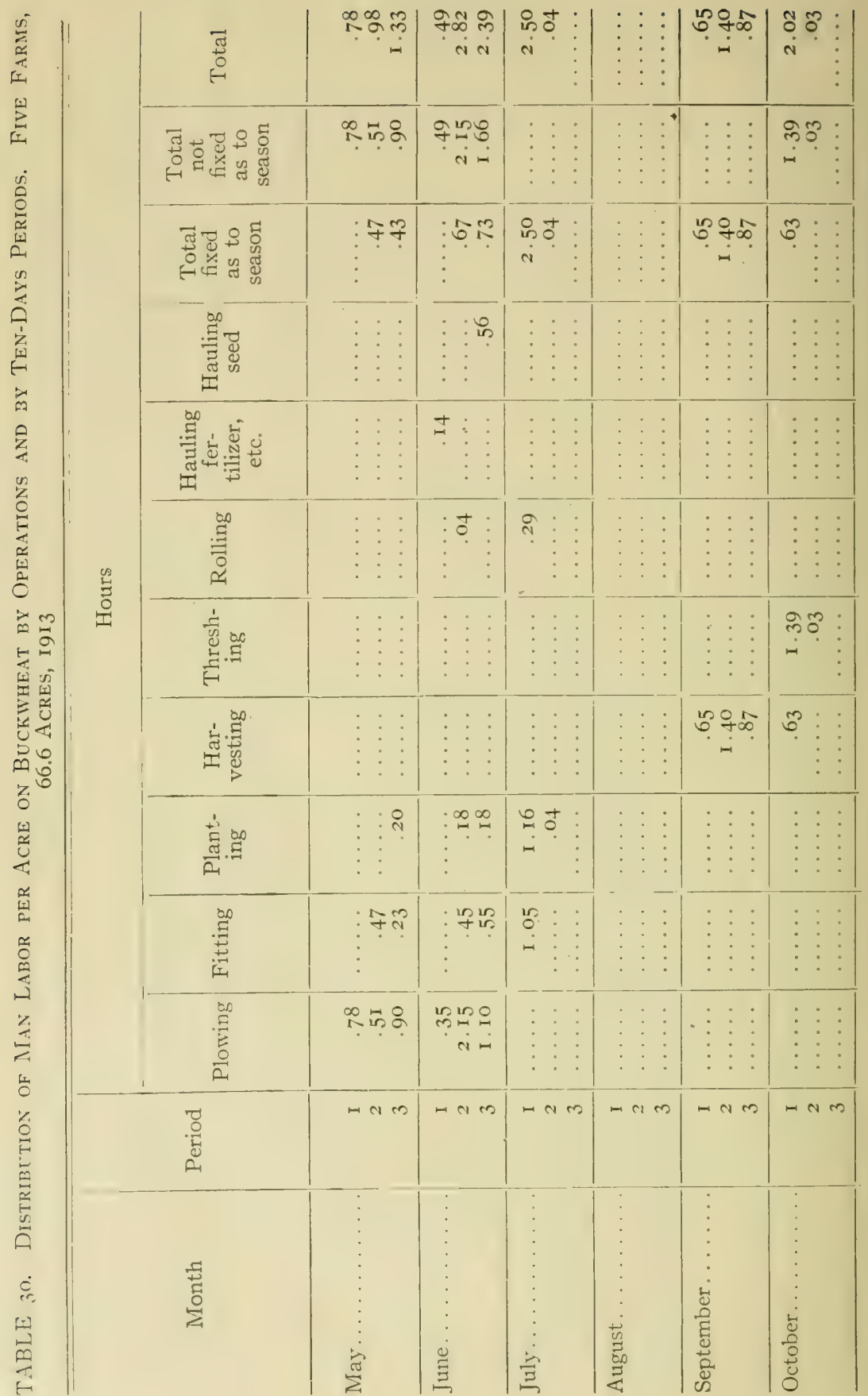




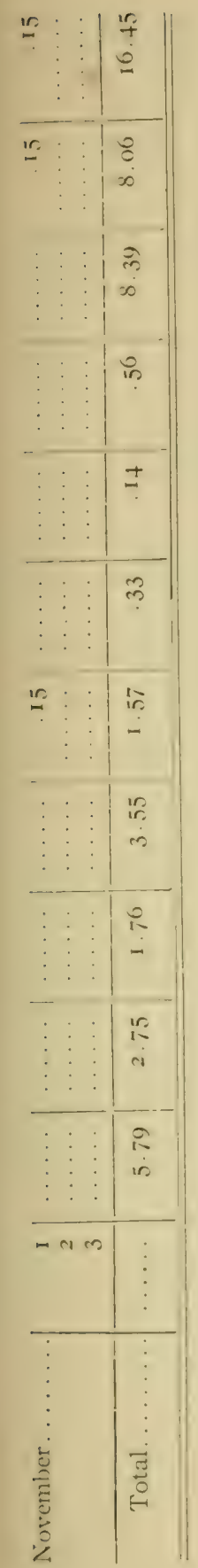


table 3i. Distribution of Man labor per Cattle UTit on Grade Cows by (Operations and by Ten-Days Periods. Five Farms, 173.25 Cattle Units, 1913

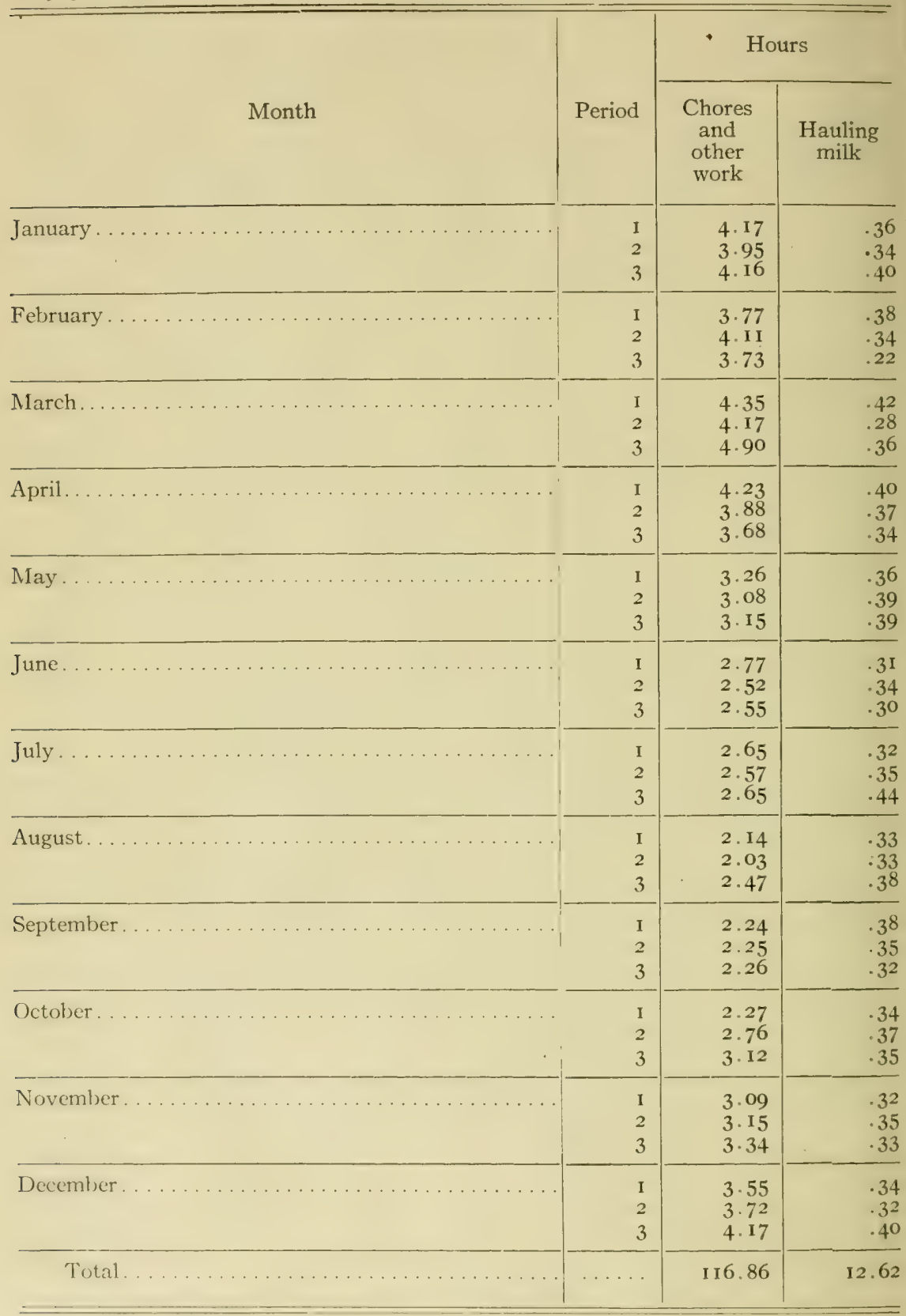


TABIE 32. DISTRIBETION OF HORSE L.MIOR PER A(RE (N TIMUTHY ANI) CIOTER

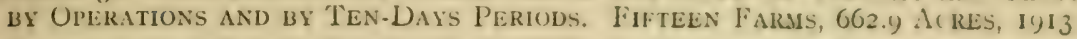

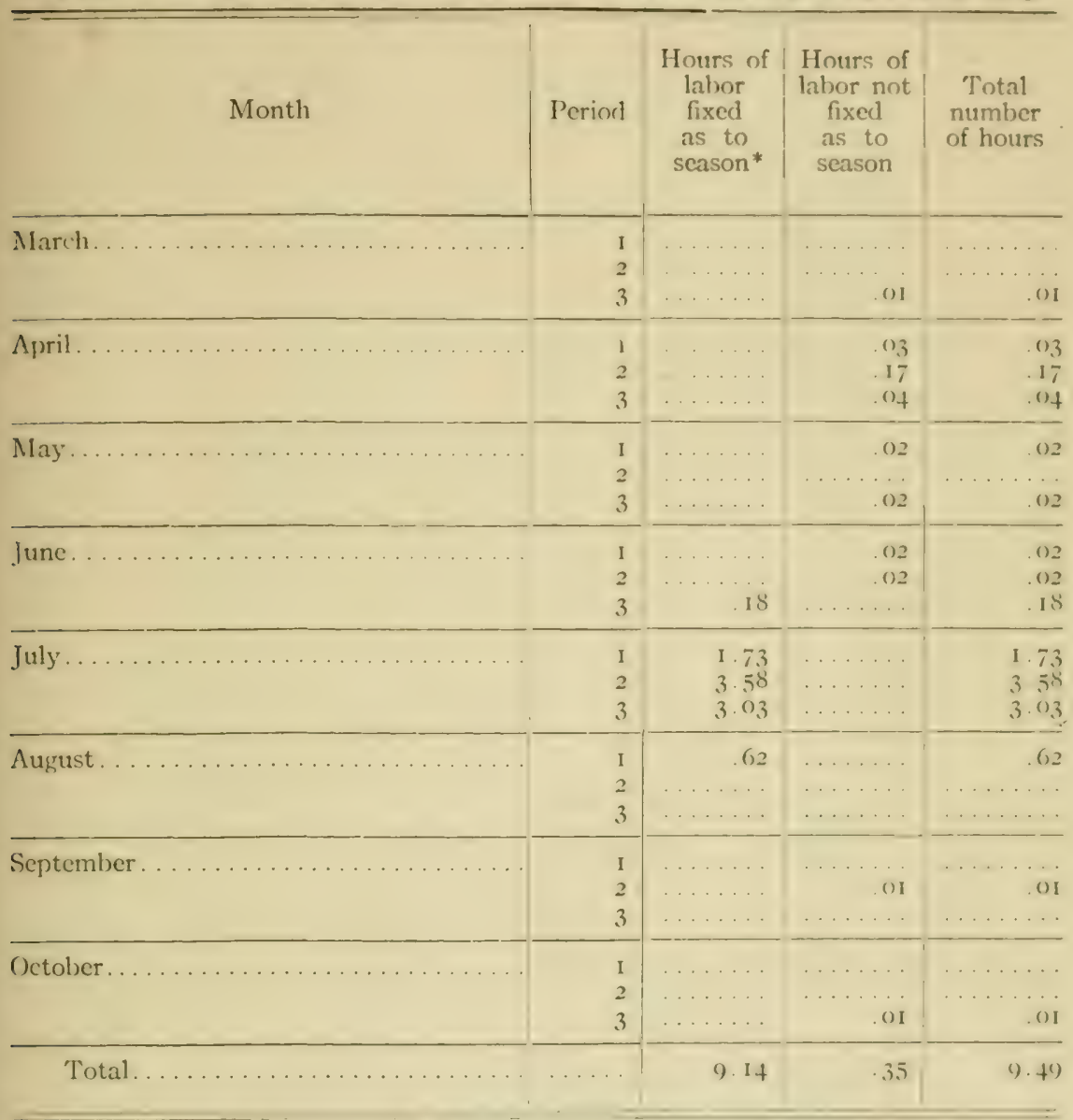

*The fixed labor was all harvesting. The labor not fixed was seeding, rolling, and other miscellanenus operations. 


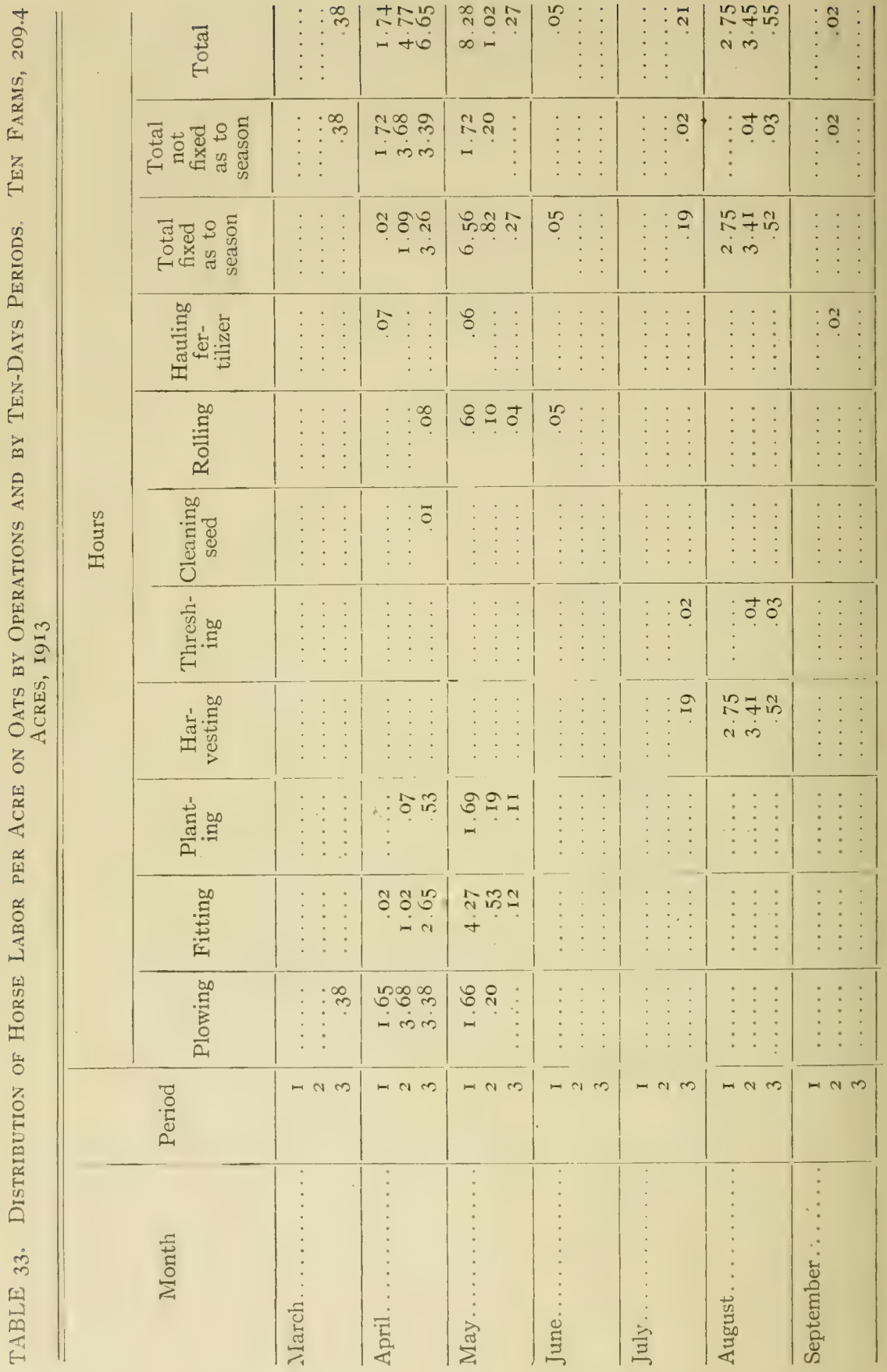



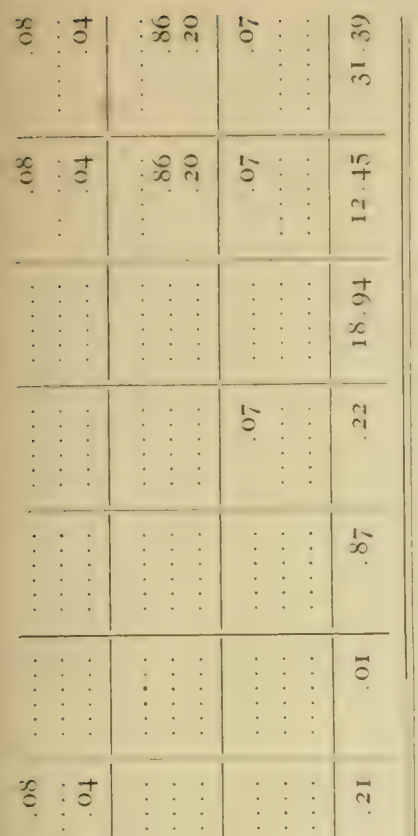

$\vec{\imath}$

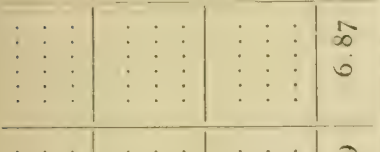

is

तi

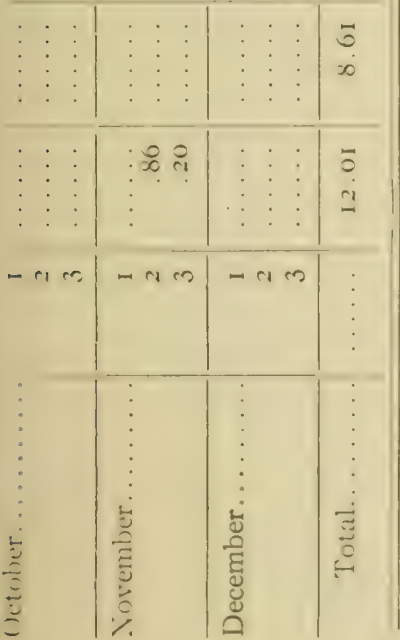




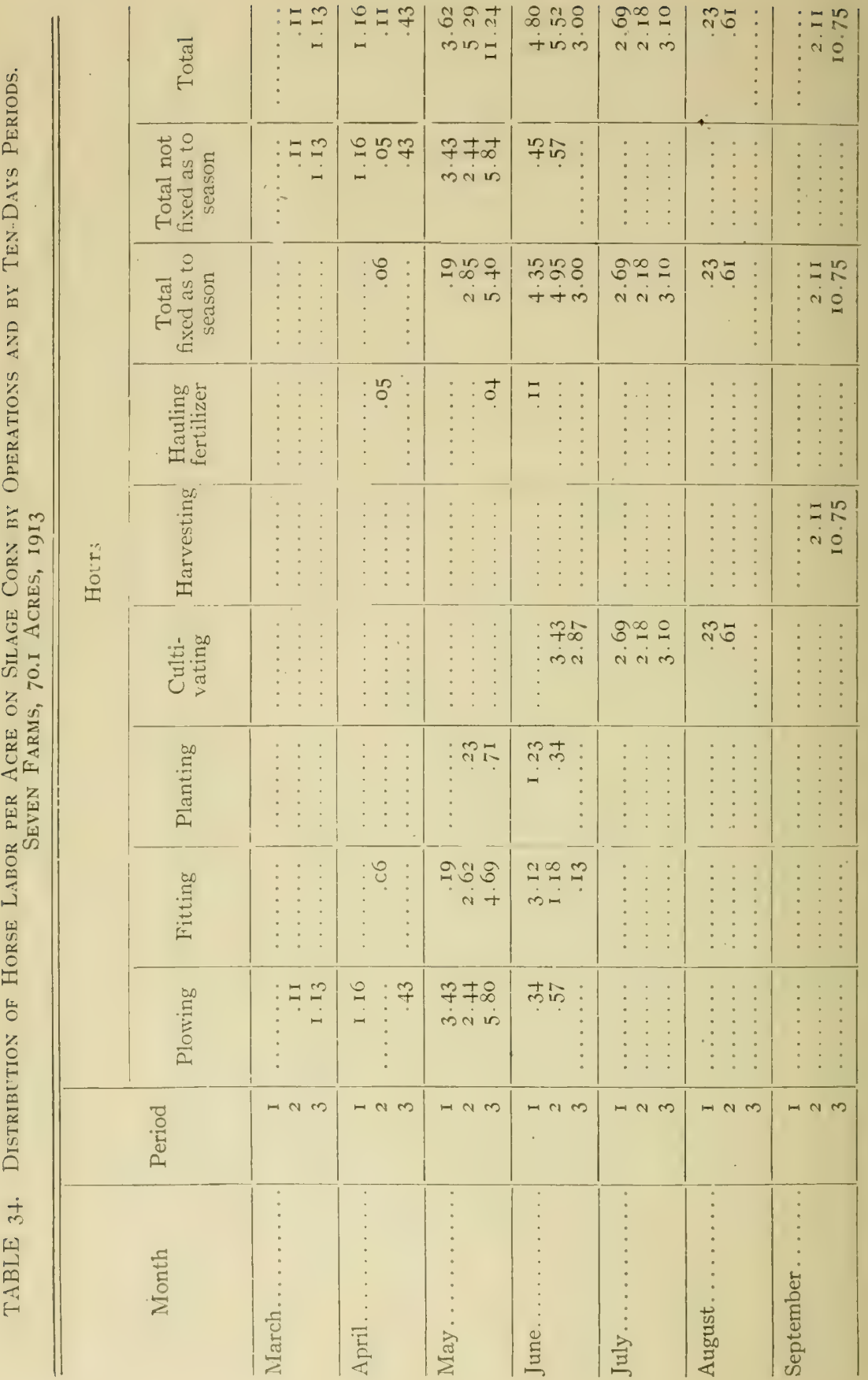




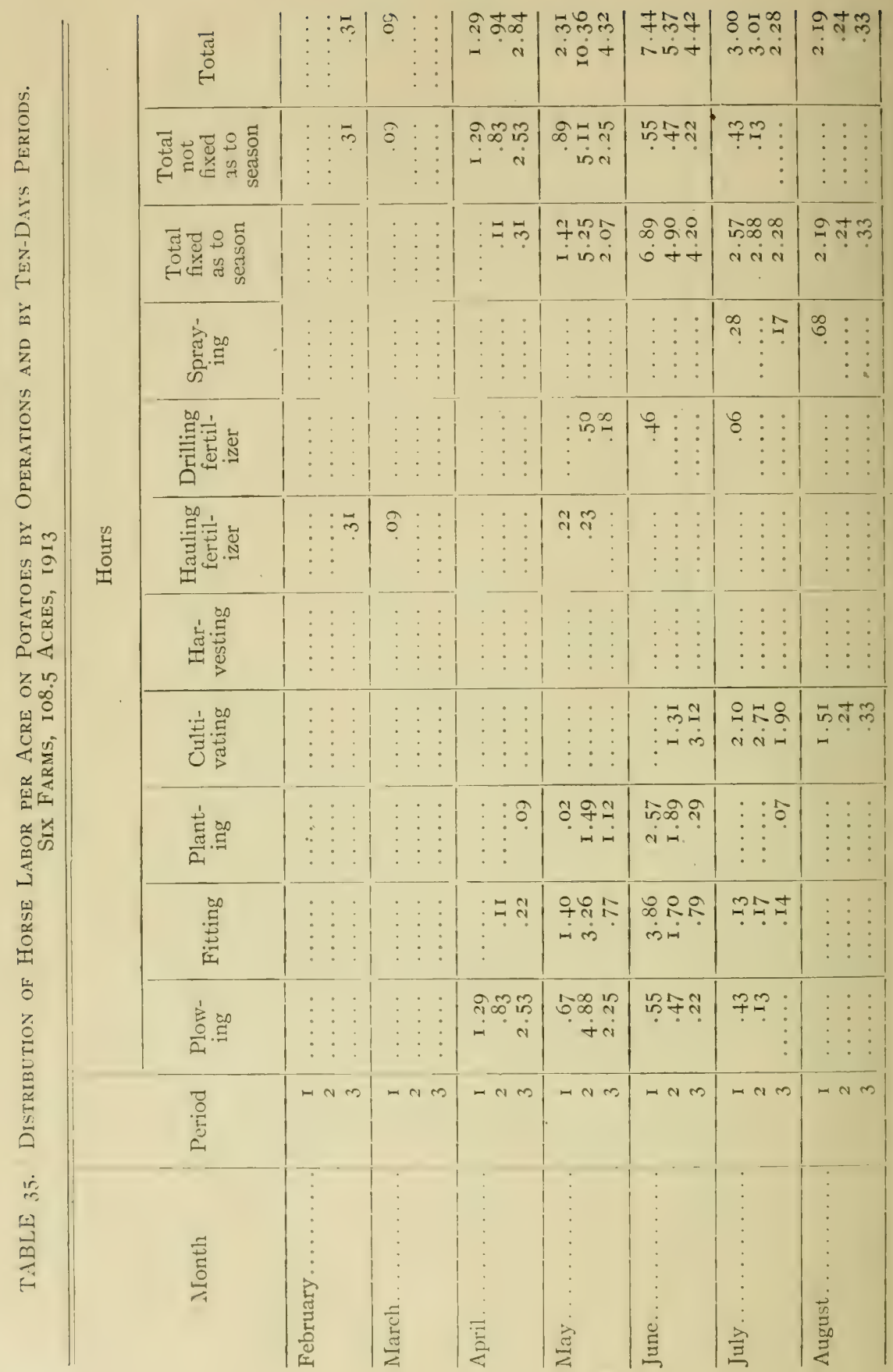




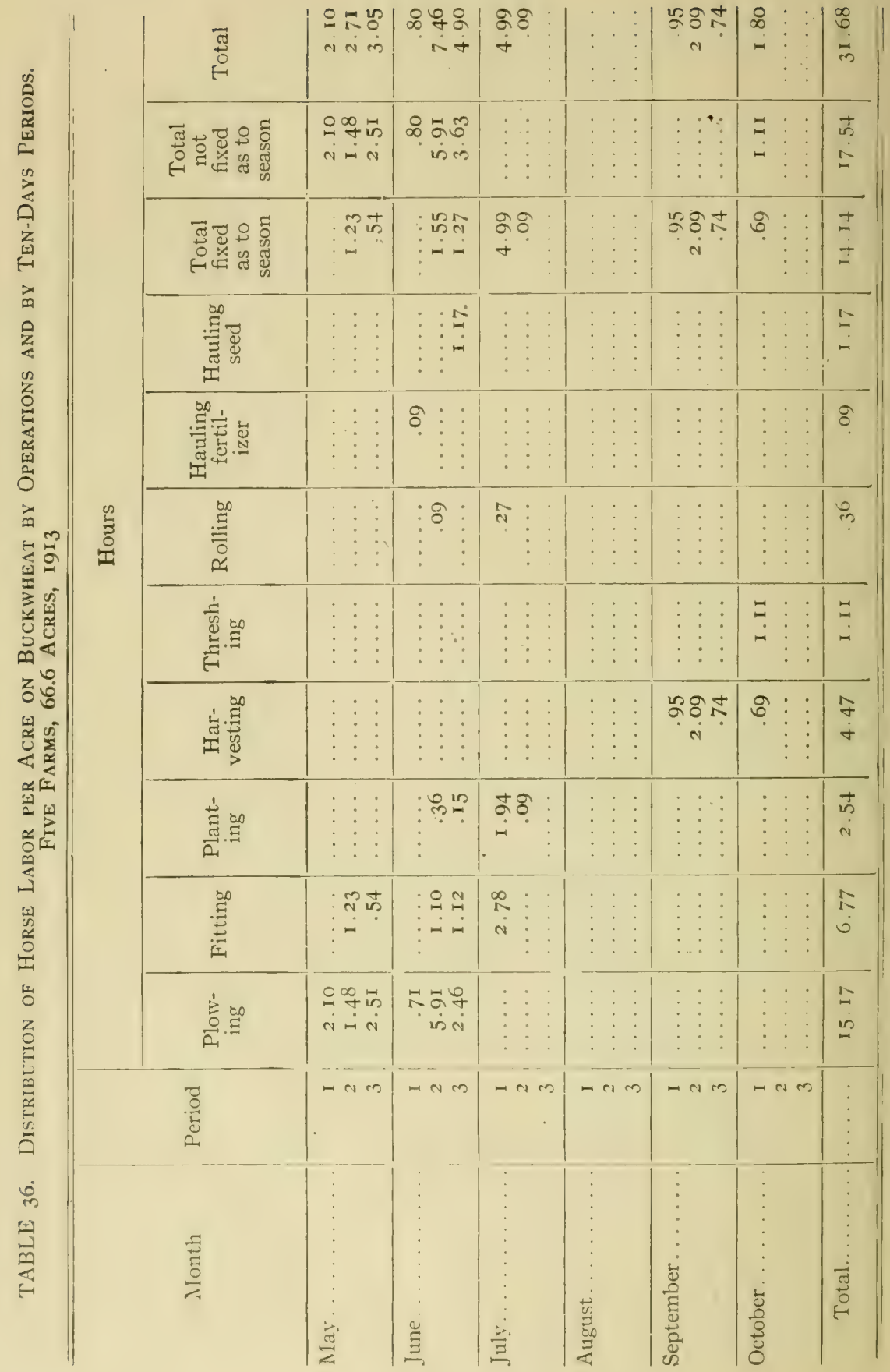




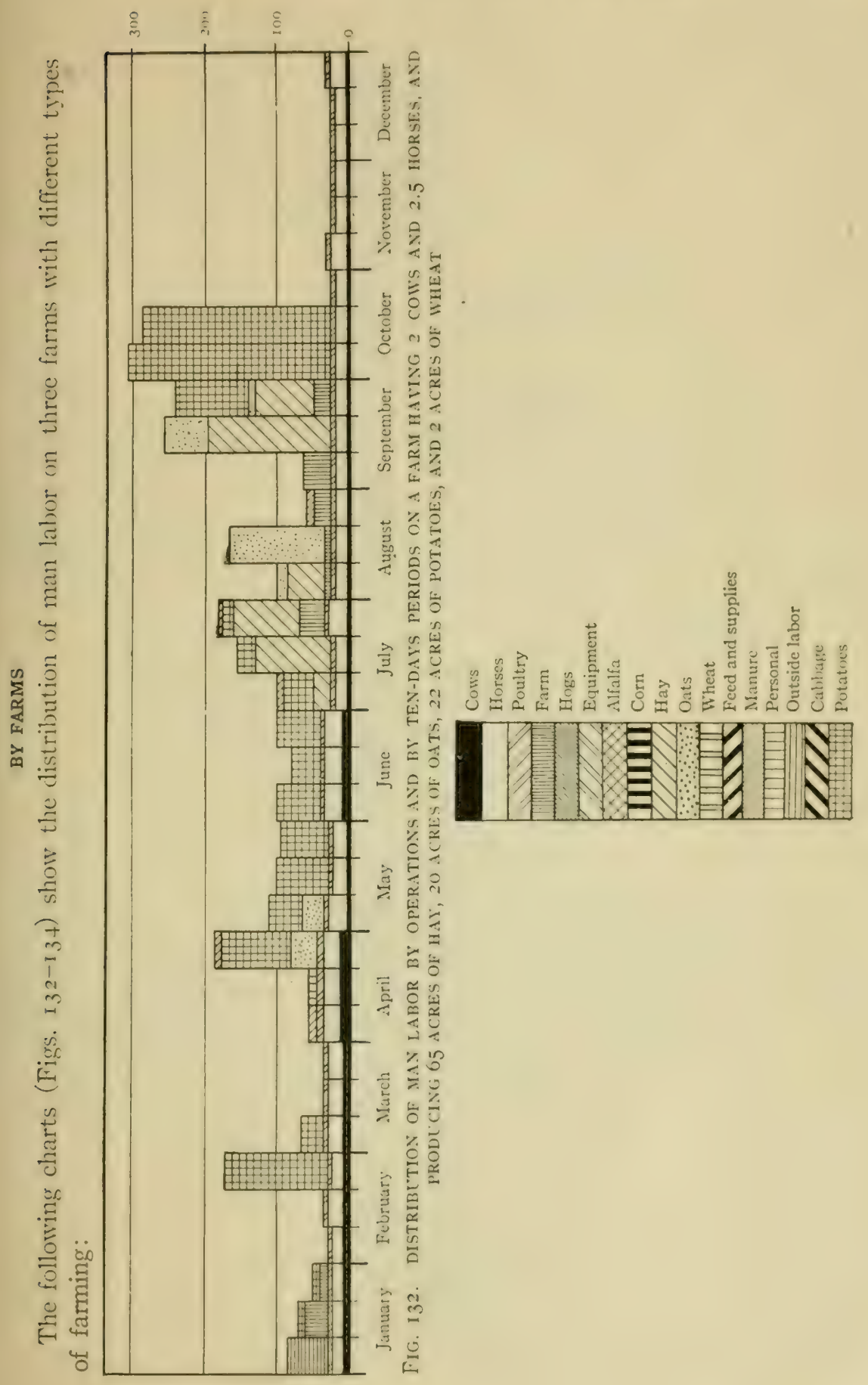




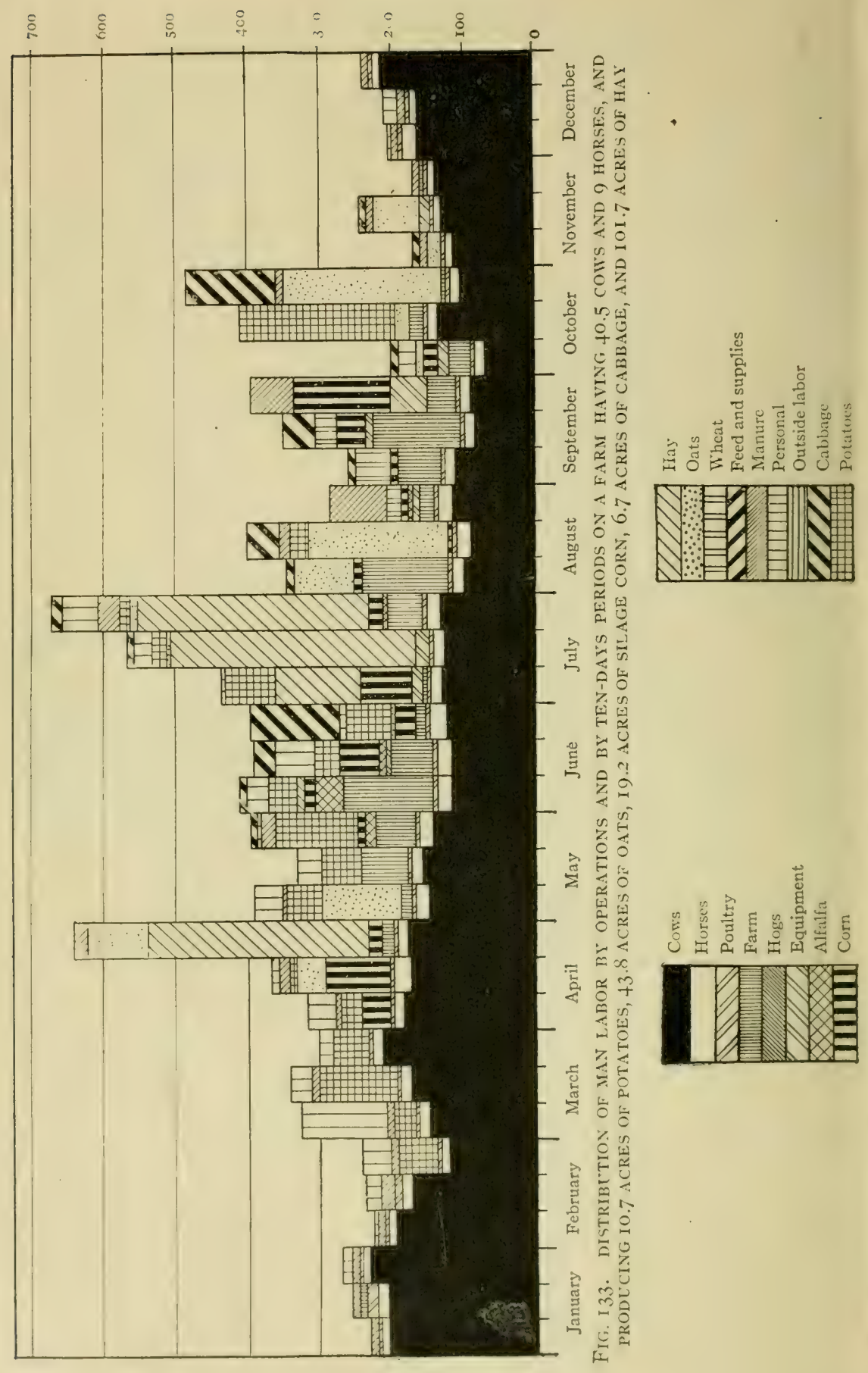




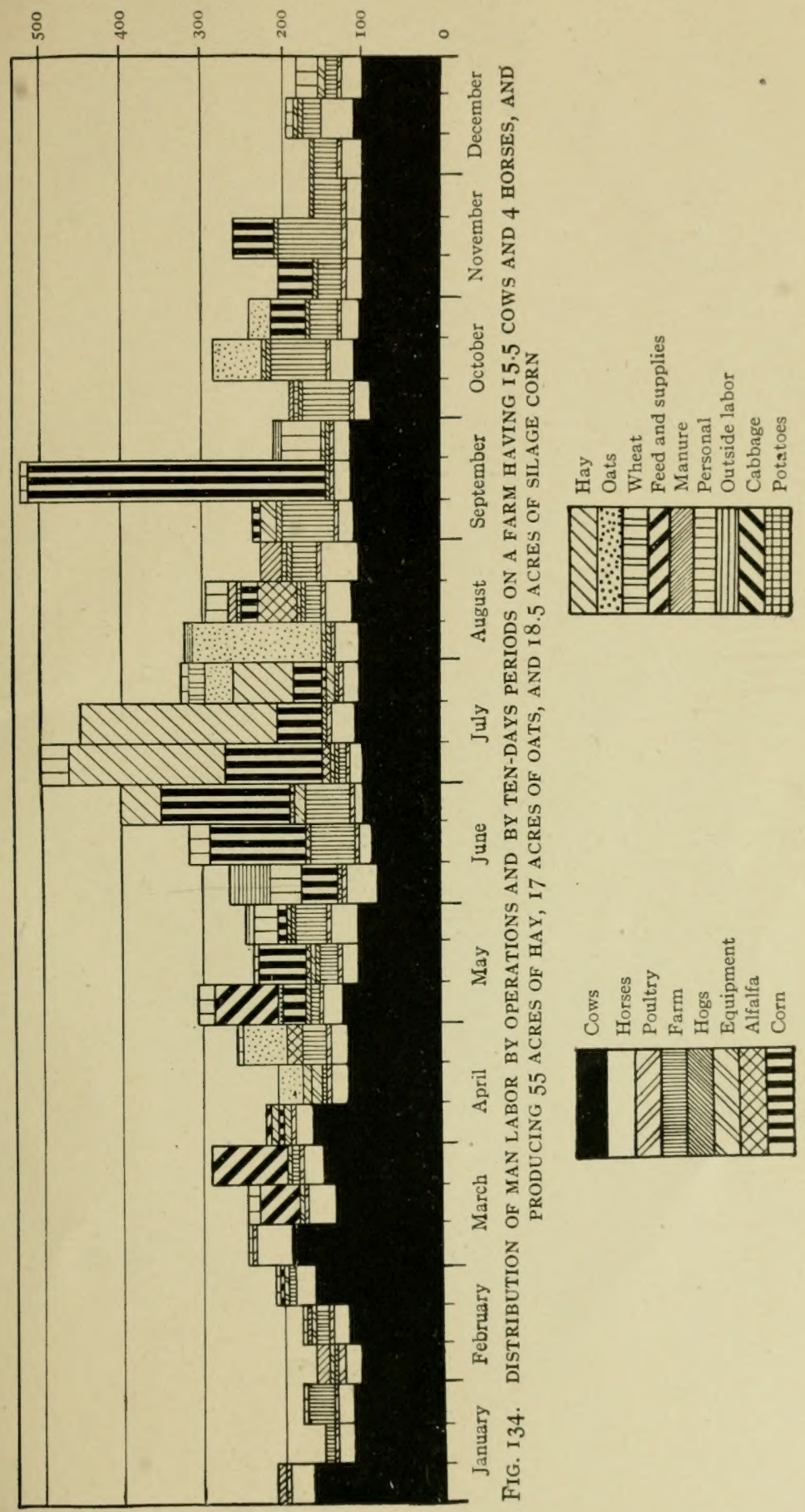






\section{LIBRARY OF CONGRESS}

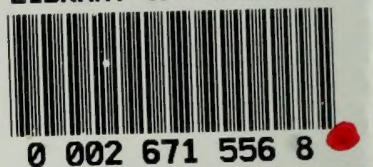

